bioRxiv preprint doi: https://doi.org/10.1101/2021.11.23.469621; this version posted November 24,2021 . The copyright holder for this preprint

(which was not certified by peer review) is the author/funder, who has granted bioRxiv a license to display the preprint in perpetuity. It is made available under aCC-BY-NC-ND 4.0 International license.

Aging Differences in LC Diffusivity

\title{
Age Differences in Diffusivity in the Locus Coeruleus and its Ascending Noradrenergic Tract
}

Shai Porat ${ }^{1}$, Francesca Sibilia ${ }^{2}$, Josephine Yoon ${ }^{1}$, Yonggang Shi ${ }^{2}$, Martin J. Dahl ${ }^{1,3}$, Markus

Werkle-Bergner ${ }^{3}$, Sandra Düzel ${ }^{3}$, Nils Bodammer ${ }^{3}$, Ulman Lindenberger $^{3}$, Simone Kühn $^{3}$, \& Mara Mather ${ }^{1}$

1. University of Southern California, Dept. of Gerontology, 2. University of Southern California, Keck School of Medicine, 3. Max Planck Institute for Human Development, Center for Lifespan Psychology. 
Aging Differences in LC Diffusivity

\begin{abstract}
The noradrenergic locus coeruleus (LC) is a small brainstem nucleus that promotes arousal and attention. Recent studies have examined the microstructural properties of the LC using diffusion-weighted magnetic resonance imaging and found unexpected age-related differences in fractional anisotropy - a measure of white matter integrity. Here, we used three datasets (Berlin Aging Study-II, N = 301, the Leipzig Study for Mind-Body-Emotion Interactions, $\mathrm{N}=220$, and Stockholm Sleepy Brain, $N=49$ ), to replicate published findings and expand them by investigating diffusivity in the LC's ascending noradrenergic bundle. In younger adults, LC fractional anisotropy was significantly lower, compared to older adults. However, in the LC's ascending noradrenergic bundle, we observed significantly higher fractional anisotropy in younger adults, relative to older adults. These findings indicate that diffusivity in the LC versus the ascending noradrenergic bundle are both susceptible to microstructural changes in aging that have opposing effects on fractional anisotropy.
\end{abstract}

\title{
Highlights:
}

- Fractional anisotropy in the locus coeruleus was lower in younger adults

- Fractional anisotropy in the noradrenergic bundle was higher in younger adults

- Sleep deprivation may affect diffusivity in younger adults more than older adults

Keywords: Locus coeruleus, noradrenergic bundle, diffusion, sleep deprivation, neuroimaging, aging 


\section{Aging Differences in LC Diffusivity}

\section{Introduction}

The locus coeruleus (LC) is the brain's primary source for noradrenaline (F. S. Giorgi et al., 2020; Khanday et al., 2016; Lee et al., 2018), influencing arousal and attention throughout the day (Aston-Jones \& Waterhouse, 2016; Dahl, Mather, Sander, et al., 2020; Mather, 2020; Mather \& Harley, 2016; McGregor \& Siegel, 2010; Sara, 2009). The LC also has widespread cortical projections that are susceptible to neurodegeneration (Aston-Jones \& Waterhouse, 2016; Loizou, 1969; Loughlin et al., 1982; Morris, McCall, et al., 2020). Notably, the human LC is the primary site of early abnormal tau pathology (Braak \& Del Trecidi, 2015; Liu et al., 2020; Mather \& Harley, 2016) and until recently, in vivo microstructural properties of the LC were mostly unexplored (Edlow et al., 2016; Edlow et al., 2012; Langley et al., 2020).

Recently, Langley et al. (2020) examined the diffusive properties of the LC using diffusion-weighted MRI. They observed higher fractional anisotropy in the LC of older adults, compared with younger adults. Fractional anisotropy is widely used as a measure of structural integrity (higher fractional anisotropy typically indicates healthier axons) and has a strong inverse correlation with mean or radial diffusivity (Bhagat \& Beaulieu, 2004; Kantarci et al., 2017; Kochunov et al., 2012). With aging, older adults typically display lower fractional anisotropy and higher mean diffusivity in white and gray matter compared with younger adults (Kantarci, 2014; D. A. Medina \& M. Gaviria, 2008; Rose et al., 2008; Sullivan \& Pfefferbaum, 2006; A. N. Voineskos et al., 2012). In addition, grey matter also typically shows lower fractional anisotropy and higher mean diffusivity in Alzheimer's disease (Kantarci, 2014; Rose et al., 2008; 
Aging Differences in LC Diffusivity

Weston et al., 2015). Langley's findings are the opposite of typical white matter age effects, though speculated to be associated with an age-related reduction in LC structure.

Given the surprising nature of the increased fractional anisotropy seen in older adults' LC compared with younger adults' LC, we were interested in testing whether these age differences replicate in larger samples. In addition, we were interested in whether the diffusivity within the LC might reflect a biomarker for transient states of inflammation or neuronal activity. Animal research suggests that inflammation restricts fluid flow (Yi et al., 2019). In addition, neuronal activity tends to swell neurons, reducing the interstitial fluid-filled spaces between them and decreasing diffusivity (Abe et al., 2017; Iwasa et al., 1980; Le Bihan et al., 2006; Nunes et al., 2021; Svoboda \& Syková, 1991). Sleep deprivation affects both neuronal activity and inflammation and so we also examined whether a sleep deprivation manipulation would affect LC fractional anisotropy.

Unmyelinated neurons and numerous innervations to blood capillaries may expose the LC to toxins throughout aging (Bekar et al., 2012; Giorgi et al., 2020; Raichle et al., 1975). During the waking day, the LC has a high constant spiking rate which accumulates oxidative stress in the mitochondria of LC neurons (Weinshenker, 2018). In addition, excess noradrenaline not repackaged into synaptic vesicles promotes LC tau pathology (Kang et al., 2020). A lack of sleep, in particular REM sleep when the LC is least active (Takahashi et al., 2010), results in LC and amygdala hyperactivity (Goldstein \& Walker, 2014; Khanday et al., 2016). Larger LC volume has been observed in patients with pathological anxiety (Morris, Tan, et al., 2020), which may be related to enhanced connectivity between the LC and amygdala (Giustino et al., 2020). 
Aging Differences in LC Diffusivity

Using two large datasets (Berlin Aging Study-II, $N=301$, (Delius et al., 2015), and the Leipzig Study for Mind-Body-Emotion Interactions, $N=220$, (Babayan et al., 2019) of healthy young and older adults, we examined whether we could replicate LC fractional anisotropy findings as reported by Langley, et al., and compare them with the ascending noradrenergic bundle, which originates in the LC. To characterize diffusion properties within the ascending noradrenergic bundle, we relied on a probabilistic atlas of bilateral ascending noradrenergic fiber bundles originating in the LC and terminating in the transentorhinal cortex based on data from the Human Connectome Project (Sun et al., 2020; Tang et al., 2018). To test whether diffusivity in the LC is sensitive to short-term changes, we turned to a third dataset, the Stockholm SLEEPY Brain, final $N=49$, which provides an opportunity to further investigate LC diffusivity under the context of sleep deprivation (Akerstedt, 2016).

\section{Methods}

Demographics and MRI sequence information across all three datasets can be found in Tables 1 through Table 4. The first dataset we examined is the Berlin Aging Study II (BASE-II) (Bertram et al., 2014; Delius et al., 2015) from timepoint two. BASE-II information can be found online (https://www.base2.mpg.de/en). In short, BASE-II is a multi-disciplinary and multiinstitutional longitudinal study sampling from Berlin's population. Because the BASE-II study included LC-MRI contrast measures, we asked whether these measures were associated with measures of LC and noradrenergic bundle diffusivity. The LC-MRI index potentially reflects neuromelanin accumulation as a byproduct of NE synthesis. Hence, it is supposed to indicate functional NE-density within the LC. If a lower LC-MRI contrast indeed reflects impaired 
Aging Differences in LC Diffusivity

functionality of the LC-NE system, detrimental downstream effects on pathways connecting the LC to the entorhinal cortex might be expected. Hence, we expect lower LC-MRI contrast ratios to be associated with lower diffusivity. BASE-II LC-MRI contrast values were previously quantified in a different study (Dahl et al., 2019).

The second dataset we examined is the Leipzig Study for Mind-Body-Emotion Interactions (LEMON), for which extensive details can be found elsewhere (Babayan et al., 2019). This cross-sectional study contains both young and older adults from Leipzig and the surrounding area. The final dataset we examined is the Stockholm SLEEPY Brain Study (Akerstedt, 2016). In this dataset, participants were instructed to maintain normal sleep patterns (sleep rested) or go to sleep 3 hours before waking up at their normal wake times (e.g., if a participant typically wakes up at 8am, for the sleep deprivation condition they would go to sleep at 5am but still wake up at 8am), to mimic real-world sleep deprivation.

Although the SLEEPY Brain study had two time points per participant (one sleep rested, one sleep deprived), only one time point included a diffusion-weighted scan, and therefore each participant was either in the sleep-rested or sleep-deprived condition, during diffusion scanning. Subject demographics in this study, with final N's per dataset, are displayed in Table 1. We excluded subjects with poor quality diffusion-weighted scans, poor atlas registration, or missing data in statistical analyses. Poor scan and registration quality was determined through visual inspection. Tables 2-4 contain LC-MRI contrast sequence parameters, structural MRI parameters, and diffusion-weighted MRI parameters across studies, respectively.

\subsection{DWI Processing}


Aging Differences in LC Diffusivity

Using University of Southern California's Laboratory of Neuroimaging (LONI) Pipeline, we applied FSL's (v6.3) eddy-current correction, brain extraction tool, and resampling to isotropic resolution of $2 \mathrm{~mm}^{3}$ (Dinov et al., 2009; Smith et al., 2004). We used MRtrix (v3.1) to compute fractional anisotropy (FA) and eigenvalue images (Tournier et al., 2019). Our atlas of the right and left LC nuclei was obtained from a LC meta-mask (Dahl et al., 2021) and the right and left noradrenergic bundles from Tang et al. (2020). As control regions, we utilized the previously defined right and left frontopontine tracts (Tang et al., 2018), which run along the ventral portion of the pons on either side of the basilar sulcus, terminating at the pontine nuclei. Figure 1 displays all three ROIs in MNI152 linear, $1 \mathrm{~mm}$ resolution space.

Both fractional anisotropy and atlas images were registered into MNI152 linear, 1mm brain space. Using ANTS nonlinear registration (Avants et al., 2008; Sun et al., 2020) the atlases were then backwarped into individual subject space with nearest neighbor interpolation. Registration quality was visualized using an in-house MATLAB script (MATLAB ver. R2019a). After accurate atlas registration to individual subject space was confirmed with visual inspection, mean and radial diffusion images were created from eigenvalue images in MATLAB with custom scripts. Atlases were then converted into a binary mask and multiplied by the diffusion image to provide fractional anisotropy, mean, and radial diffusivity values along the atlases, per voxel, within the native space. Diffusivity values were then averaged to provide one value per participant per ROI.

Since the noradrenergic bundle overlaps with a portion of the LC atlas, we conducted an along-tract analysis of fractional anisotropy of the noradrenergic bundle. 50 equidistant points 
Aging Differences in LC Diffusivity

were imposed along the noradrenergic bundle as discussed elsewhere (Sun et al., 2020). Each point was averaged across participants within younger or older adult groups. Anatomically, approximately the first 10 points represent most of the LC and points $30-50$ represent areas of the entorhinal cortex. Fractional anisotropy at each point along the tract was compared between younger and older adults, shown in Figures 6-8.

\subsection{Statistical Analyses}

All statistical analyses were conducted using the R software (Team, 2020) with tidyverse and various additional packages (Ahlmann-Eltze, 2019; Aust \& Barth, 2020; Kassambara; Lenth, 2021; Sjoberg et al., 2021; Wicham, 2017; Wickham, 2016; Xie, 2021). Correlation coefficients and $95 \%$ confidence intervals were used to identify the relationship between LC-MRI contrast and diffusivity measurements. Diffusivity and fractional anisotropy, mean diffusivity, and radial diffusivity values in the LC, ascending noradrenergic bundle, and frontopontine tract were analyzed within each dataset using a $2 \times 2 \times 3 \times 2$ factorial design in which age (younger, older) and gender (female, male) were between-subject factors and ROI (noradrenergic bundle, locus coeruleus, frontopontine tract) and hemisphere (left, right) were repeated-measures factors.

Levene's tests were used to explore ANOVA assumptions of equal variances. We report effect sizes using $\hat{\eta}_{G}^{2}$ (generalized eta squared) for ANOVA effects and provide 95\% confidence intervals to allow for comparisons across means. Greenhouse-Geisser correction was automatically computed for ANOVA departures from sphericity. For the along-tract analyses, $t$ tests were conducted for fractional anisotropy at each of the 50 equidistant points between younger and older adults. $P$ values were false-discovery rate adjusted and surviving points of 
Aging Differences in LC Diffusivity

significant FA differences between age groups are plotted in Figures 6-8. Our focus was on fractional anisotropy but we include mean and radial diffusivity findings in the supplementary material. Lastly, to investigate if LC-FA diffusivity is associated with noradrenergic bundle-FA diffusivity, we conducted Pearson correlations and t-tests for each dataset.

\section{Results}

\subsection{LC-MRI Contrasts and DTI}

In the BASE-II dataset, there were no significant differences between young and older adults' overall LC-MRI contrast values (Bachman et al., 2021; Dahl et al., 2019). We also did not observe significant associations between LC-MRI contrast and diffusivity in either the LC or ascending noradrenergic bundle. Correlation coefficients with FA and 95\% confidence intervals for younger and older adults are displayed in Table 5 and Table 6, respectively. Previous studies have observed no overall age differences, but spatially confined age differences between caudal and rostral regions of the LC have been observed with LC-MRI contrast (Bachman et al., 2021; Dahl et al., 2019).

\subsection{Fractional anisotropy in the LC is higher in older adults, relative to younger adults}

Complete ANOVA tables for fractional anisotropy across datasets are displayed in Tables

7-9. Here in the text, we report the significant ANOVA interactions involving Age and ROI. In the BASE-II and LEMON datasets, we observed a significant interaction of Age $x$ ROI for fractional anisotropy, $F(1.57,468.27)=27.18, p<.001, \hat{\eta}_{G}^{2}=.033$, and $F(1.79,386.34)=26.07, p<.001, \hat{\eta}_{G}^{2}$ $=0.035$, respectively (Table 7 and Table 8 ). We also observed a significant 3-way interaction of 
Aging Differences in LC Diffusivity

Age $\times \mathrm{ROI} \times$ Hemisphere for fractional anisotropy, $F(1.62,483.01)=6.49, p=.003, \hat{\eta}_{G}^{2}=.05$, and

$F(1.63,352.15)=5.50, p=.008, \hat{\eta}_{G}^{2}=0.04$, in the BASE-II and LEMON datasets, respectively.

Tables 10 and 11 report means and 95\% confidence intervals for fractional anisotropy

for each ROI between age groups, in each hemisphere. We observed significantly less fractional anisotropy in the LC and significantly more fractional anisotropy in the noradrenergic bundle of younger adults compared to older adults, in both the BASE-II and LEMON datasets (Tables 10 and 11; Figures 2 and 3). We observed no significant differences in frontopontine tract fractional anisotropy between younger and older adults in either BASE-II or LEMON datasets.

For the SLEEPY Brain dataset, we used the same ANOVA factorial design as in the other datasets with sleep condition (rested, deprived) as an additional between-subjects factor. The Age $x \mathrm{ROI}$ interaction did not quite reach significance, $F(1.76,72.17)=3.09, p=.058, \hat{\eta}_{G}^{2}=0.03$, (Table 9). Likewise, the Age $\times$ ROI x Sleep Condition interaction did not quite achieve significance, $F(1.76,72.17)=3.12, p=.056, \hat{\eta}_{G}^{2}=0.031$. Here, we report planned contrasts of fractional anisotropy across ROls between age groups and sleep conditions. Means and confidence intervals for the SLEEPY dataset are available in Table 12, and plots for between and within age group differences are shown in Figures 4 and 5, respectively.

In the sleep rested condition, we observed no significant differences in fractional anisotropy between young and older adults in the left or right $L C, t(41)=0.181, p=.857$, and $t(41)=1.469, p=.149$, respectively. We observed no significant differences in fractional anisotropy between sleep rested young and older adults in the left noradrenergic bundle, $t(41)$ $=.619, p=.539$, but significantly higher fractional anisotropy in the right noradrenergic bundle 
Aging Differences in LC Diffusivity

of sleep rested younger adults, compared to older, $t(41)=2.56, p=.014$. Similarly, we observed no significant differences in fractional anisotropy between sleep rested young and older adults in the left frontopontine tract, $t(41)=0.838, p=.407$, but significantly higher fractional anisotropy in the right frontopontine tract of sleep rested younger adults, compared to older, $t(41)=2.161, p=.036$.

Within the sleep deprived condition, younger adults had lower fractional anisotropy than older adults in the LC that did not quite achieve significance in the left locus coeruleus, $t(41)=-1.658, p=.104$, but was significant in the right locus coeruleus, $t(41)=-2.451, p=.018$. We also observed significantly higher fractional anisotropy in sleep deprived younger adults, compared with older adults, in both the left and right noradrenergic bundle, $t(41)=3.286, p=$ .002 and $t(41)=4.291, p<.001$, respectively. No significant differences were observed between younger and older adult's fractional anisotropy in the sleep deprived conditions in the left or right frontopontine tract, $t(41)=0.163, p=.870$, and $t(41)=0.296, p=.769$, respectively.

The BASE-II and LEMON along-tract analyses (Figure 6-7) show effects that are consistent with the LC and noradrenergic bundle results described above. Along the first 10 points, which approximately represent regions close to the LC, younger adults display significantly lower fractional anisotropy, relative to older adults. In the remaining tract points, younger adults had higher fractional anisotropy, relative to older adults, with significant age differences toward the end of the tract, in the region of the entorhinal cortex. We did not observe significant differences along the noradrenergic bundle between younger and older adults in the SLEEPY dataset, to the degree observed in the BASE-II and LEMON datasets. 
Aging Differences in LC Diffusivity

Finally, we observed significant positive correlations between LC fractional anisotropy and noradrenergic bundle fractional anisotropy within the BASE-II older adult cohort in the left and right hemispheres, $r(243)=.24, p<.001$ and $r(243)=.19, p<.001$, respectively. However, only three percent of the variance was accounted for $\left(R^{2}\right.$ adj $\left.=0.03\right)$. We did not observe any significant relationship in the BASE-II young adult cohort. We were also not able to replicate these findings in the LEMON or SLEEPY datasets.

\section{Discussion}

Fractional anisotropy has been well established to correlate with white matter integrity, increasing until the age of about 35-40 and decreasing into late life or with disease (Kochunov et al., 2012; Li et al., 2016). Additionally, mean, and radial diffusivity are typically negatively correlated with fractional anisotropy (Beaudet et al., 2020; Li et al., 2016). Here, using three publicly available datasets (Akerstedt, 2016; Babayan et al., 2019; Delius et al., 2015), we examined the age-related diffusivity of the LC, ascending noradrenergic bundle, and, as a control, frontopontine white matter tracts. We replicated Langley et al.'s (2020) findings of higher fractional anisotropy in the LC in older adults compared with younger adults, across two large datasets (BASE-II; LEMON).

Interestingly, we did not observe these differences in the locus coeruleus in the SLEEPY Brain dataset, between young and older adults, who were sleep rested, but only those who were sleep deprived. We did, however, observe typical age differences in diffusivity of the noradrenergic bundle in sleep rested and sleep deprived young and older adults. Post-hoc analyses of the SLEEPY dataset revealed significant differences in LC fractional anisotropy 
Aging Differences in LC Diffusivity

between sleep rested and sleep deprived young adults, but not between sleep rested and sleep deprived older adults.

While fractional anisotropy tended to be higher in older than younger adults within the LC itself, older adults typically showed lower fractional anisotropy than younger adults along the noradrenergic bundle white-matter ascending tract, a typical age-related pattern in white matter (Medina \& Gaviria, 2008; Sibilia et al., 2017; Sullivan \& Pfefferbaum, 2006; Voineskos et al., 2012). The lack of associations observed in our datasets between LC fractional anisotropy and noradrenergic bundle fractional anisotropy may suggest these two regions are affected by diffusivity independently.

In the BASE-II and LEMON datasets, this age difference in the noradrenergic bundle contrasted with a lack of age differences in the right and left control white-matter frontopontine tracts, suggesting that the age effects in the noradrenergic ascending tract reflect more than just a global change in white matter. Thus, together, these data indicate that diffusivity properties of the LC and its ascending noradrenergic tract are affected by aging in opposite ways. Our findings of age differences in fractional anisotropy in the LC and its ascending tracts extend a growing set of observations of age differences in the structure of the LC in aging (Chen et al., 2014; Dahl et al., 2021; Dahl, Mather, Werkle-Bergner, et al., 2020; Langley et al., 2020; Morris, Tan, et al., 2020; Sun et al., 2019).

To date, most in vivo findings of LC structure have relied on LC-MRI sequences that show a cross-sectional increase in LC-neuromelanin sensitive contrast from young adulthood until around age 57, at which point it levels off or declines (Liu et al., 2019), potentially 
Aging Differences in LC Diffusivity

suggesting a gradual accumulation of neuromelanin followed by noradrenergic degeneration.

One of the three data sets we examined (BASE-II) included neuromelanin-sensitive scans, and

there were no significant correlations between LC-MRI contrast from those scans and diffusivity

measures from the LC or noradrenergic bundle. This suggests that the diffusivity differences

reflect different structural changes than the neuromelanin-sensitive scans. An important future

research question is to expand the relationship between LC diffusivity measures and cognition,

or markers of brain health, as has been found for LC-MRI contrast (Clewett et al., 2016; Dahl et

al., 2019; Langley et al., 2020). One initial study along these lines found that medial and radial

diffusivity in the LC-thalamus tract was correlated with memory performance in an older cohort

(Langley et al., 2021).

Our results raise the question of what properties of the LC are changing to lead its tissue

to show higher fractional anisotropy with age. One possibility could be an increase in

inflammation that restricts fluid flow, as animal research has demonstrated that increases in

microglial density affect diffusivity, as measured using an orientation dispersion index (Yi et al.,

2019). In general, sleep disruption is associated with increased inflammation (Irwin et al., 2016).

If greater inflammation within the LC were driving the baseline age differences seen in the

BASE-II and LEMON data sets, we would expect sleep deprivation to make younger adults' LC

fractional anisotropy resemble that of older adults more. However, sleep deprived younger

adults showed significantly lower LC fractional anisotropy than sleep rested younger adults.

Another possibility is that the age differences in LC diffusivity relate to age differences

in LC tonic activity levels. Although still an open question, various findings suggest that the LC is 
Aging Differences in LC Diffusivity

more tonically active in aging (Mather, 2020; Weinshenker, 2018). Age differences in tonic levels of LC could contribute to differences in diffusivity as neuronal activity increases neuronal volume, while shrinking the volume of the surrounding fluid-filled spaces (Abe et al., 2017; Iwasa et al., 1980; Le Bihan et al., 2006; Nunes et al., 2021; Svoboda \& Syková, 1991; Tirosh \& Nevo, 2013) However, sleep reduces LC activity (Hayat et al., 2020; Khanday et al., 2016; Takahashi et al., 2010), so this potential mechanism would not be consistent with the opposing effects of aging and sleep deprivation.

Recent sleep deprivation studies looking at more global diffusivity have observed similar changes in fractional anisotropy (Elvsåshagen et al., 2015; Voldsbekk et al., 2021; Voldsbekk et al., 2020). Specifically, fractional anisotropy increased throughout the waking day, but decreased during sleep deprivation in relation to increased radial diffusivity and decreased axial diffusivity (Elvsåshagen et al., 2015; Voldsbekk et al., 2020). Notably, fractional anisotropy has been positively correlated with increased sleep quality (Khalsa et al., 2017).

More generally, older adults accrue sleep problems throughout life that eventually result in occasional to frequent bouts of sleep loss and the effects of sleep deprivation may not be as pronounced when compared to younger adults (Lavoie et al., 2018; Mander et al., 2016). For instance, adolescents experience greater changes in mood and anxiety after sleep deprivation than do older adults (Talbot et al., 2010). Likewise, young adults show more attentional deficits after sleep deprivation than do older adults (Zitting et al., 2018). The current results raise the question of whether some of the emotional changes seen after sleep deprivation in young adults are related to microstructural changes in the LC. 
Aging Differences in LC Diffusivity

Mean and radial diffusivity in the LC also showed some age differences (results and tables provided in the supplementary material), although not as pronounced as fractional anisotropy. In the BASE-II dataset, mean diffusivity in the LC was significantly higher in younger adults, compared to older adults. In the LEMON dataset, mean diffusivity was significantly higher in the left LC of younger adults, compared to older adults. Though the cause for these laterality effects is not known, the BASE-II dataset is composed of mostly older adults, while the LEMON has more younger adults. Given the LC's proximity to the fourth ventricle, older adults may be susceptible to neurodegeneration within the LC as well as partial volume effects (Langley et al., 2020; Liu et al., 2017; Sun et al., 2020).

Interestingly, with the SLEEPY Brain dataset, we observed expected age differences in the LC of sleep rested adults, with lower mean and radial diffusivities in younger adults, relative to older adults. In the sleep deprived condition, we did not observe significant differences in LC mean and radial diffusivities between age groups. These lack of LC differences in the age comparison of sleep deprived subjects is possibly due to within age group differences of sleep deprived, compared to sleep rested, young adults. Specifically, younger adults displayed higher mean and radial diffusivity in the LC when sleep deprived, compared with sleep rested young adults. Meanwhile, levels of diffusivity within older adults between sleep rested and sleep deprived conditions remained relatively unchanged.

Because the noradrenergic bundle overlaps with the LC atlas, we conducted an alongtract analysis for the noradrenergic bundle fractional anisotropy. As expected, we observed significantly lower FA in the first 10 points of the noradrenergic bundle, which anatomically 
Aging Differences in LC Diffusivity

approximately represent regions of the locus coeruleus, in younger adults compared with older adults. However, these significant differences were not observed as strongly in the SLEEPY dataset. We suspect this may be due to the low sample size in the SLEEPY dataset that is then further split by age and sleep condition. Changes in radial diffusivity along the noradrenergic bundle of cognitively impaired older adults from the Alzheimer's Disease Neuroimaging Initiative were significantly greater, compared to healthy controls, around the area of the LC and again as the tract approached the hippocampus (Sun et al., 2020).

Early Alzheimer's pathology associated with dysfunction of sleep has been suggested to appear decades before cognitive deficits (Benveniste et al., 2019; Cedernaes et al., 2017; Ehrenberg et al., 2018; Mander et al., 2016). Notably, in post-mortem brains, abnormal-tau pathology accumulates in the LC before appearing in cortical regions like the entorhinal cortex (Braak \& Del Trecidi, 2015; Braak et al., 2011). Though we cannot make causal claims of our sleep related diffusivity findings, future studies could provide clinical insights with follow up studies. For example, by sleep depriving a large sample of young and older adults, specifically from REM sleep (most relevant to LC and emotional activity) and studying its effects on LC diffusivity and emotion, we could better understand the relationship between LC diffusivity and emotion regulation.

While most studies comparing diffusivity in younger and older adults focus on white matter, a growing number of studies have started to examine diffusivity differences in grey matter in cortical and subcortical nuclei. Patients with Alzheimer's disease generally show less fractional anisotropy and greater mean diffusivity than age-matched healthy adults (Weston et 
Aging Differences in LC Diffusivity

al., 2015). However, studies following people with autosomal dominant familial Alzheimer's disease have found increased mean diffusivity in grey matter regions during the presymptomatic period, and older adults with significant memory decline show lower diffusivity in the posterior cingulate/precuneus region (Jacobs et al., 2013). As Langley et al., suggested, agerelated LC degeneration may result in restricted diffusion within older adults (Langley et al., 2020). Fractional anisotropy also shows a positive correlation with age in the caudate, putamen and globus pallidus in a healthy cohort aged 10-52 (Pal et al., 2011). Thus, the LC may not be the only brain region showing lower fractional anisotropy in older adults.

\subsection{Limitations}

The SLEEPY dataset is likely underpowered given the low sample size between sleep rested and sleep deprived groups and therefore all interpretations of our results should be considered for replication in a larger sleep-deprived dataset. However, this dataset is one of the few available sleep-diffusion public dataset, so these initial findings may provide motivation for future studies. Crossing fibers may also indicate opposite or unexpected relationships with diffusivity values that may be related to our unexpected findings (Lee et al., 2015; Oouchi et al., 2007). Despite the limitations of DTI, it remains a valuable tool that may help us to better understand the LC in-vivo within humans. In general, our datasets were comprised of younger and older adults that had no neurological or known sleep disorders and may not reflect the general aging population. We also did not examine axial diffusivity, which may be influenced by sleep deprivation (Elvsåshagen et al., 2015). Due to partial volume constraints, the locus coeruleus ROI may be contaminated by white matter and CSF (given the position near the $4^{\text {th }}$ 
bioRxiv preprint doi: https://doi.org/10.1101/2021.11.23.469621; this version posted November 24,2021 . The copyright holder for this preprint

(which was not certified by peer review) is the author/funder, who has granted bioRxiv a license to display the preprint in perpetuity. It is made available under aCC-BY-NC-ND 4.0 International license.

Aging Differences in LC Diffusivity

ventricle). However, given the opposite findings in the ascending white matter tract, we were still able to extract meaningful signal.

\section{Conclusions}

In this study, we identified unique associations of LC diffusivity in the context of healthy adults across three different data sets. We consistently observed lower fractional anisotropy in the locus coeruleus of younger adults, compared to older adults but higher fractional anisotropy in the ascending noradrenergic bundle of younger adults, compared to older adults. Fractional anisotropy is a measurement of structural integrity, and these age findings add to a growing literature highlighting age-related differences involving the locus coeruleus. To our knowledge, this is the first study to compare diffusivity differences in-vivo in the locus coeruleus versus noradrenergic bundle. It also is the first to compare LC diffusivity differences between sleep rested and sleep deprived young and older adults. 
bioRxiv preprint doi: https://doi.org/10.1101/2021.11.23.469621; this version posted November 24,2021 . The copyright holder for this preprint (which was not certified by peer review) is the author/funder, who has granted bioRxiv a license to display the preprint in perpetuity. It is made available under aCC-BY-NC-ND 4.0 International license.

Aging Differences in LC Diffusivity

Disclosures and acknowledgments:

No Disclosures. Research reported in this publication was supported by the National Institute on Aging of the National Institutes of Health under award number R01AG025340. 
bioRxiv preprint doi: https://doi.org/10.1101/2021.11.23.469621; this version posted November 24,2021 . The copyright holder for this preprint (which was not certified by peer review) is the author/funder, who has granted bioRxiv a license to display the preprint in perpetuity. It is made available under aCC-BY-NC-ND 4.0 International license.

Aging Differences in LC Diffusivity

\section{References}

Abe, Y., Tsurugizawa, T., \& Le Bihan, D. (2017). Water diffusion closely reveals neural activity status in rat brain loci affected by anesthesia. PLoS Biol, 15(4), e2001494. https://doi.org/10.1371/journal.pbio.2001494

Ahlmann-Eltze, C. (2019). ggsignif: Significance Brackets for 'ggplot2'. R package version 0.5.0. In.

Akerstedt, G. N. T. d. O. Å. T. S. L. J. L. N. M. S. A. F. K. F. L. (2016). The Stockholm Sleepy Brain Study: Effects of Sleep Deprivation on Cognitive and Emotional Processing in Young and Old. https://doi.org/10.18112/openneuro.ds000201.v1.0.3

Aston-Jones, G., \& Waterhouse, B. (2016). Locus coeruleus: From global projection system to adaptive regulation of behavior. Brain Research, 1645, 75-78. https://doi.org/https://doi.org/10.1016/i.brainres.2016.03.001

Aust, F., \& Barth, M. (2020). papaja: Prepare reproducible APA journal articles with R Markdown. In (0.1.0.9997 ed.).

Avants, B. B., Epstein, C. L., Grossman, M., \& Gee, J. C. (2008). Symmetric diffeomorphic image registration with cross-correlation: evaluating automated labeling of elderly and neurodegenerative brain. Med Image Anal, 12(1), 26-41. https://doi.org/10.1016/i.media.2007.06.004

Babayan, A., Erbey, M., Kumral, D., Reinelt, J. D., Reiter, A. M. F., Röbbig, J., . . Villringer, A. (2019). A mind-brainbody dataset of MRI, EEG, cognition, emotion, and peripheral physiology in young and old adults. Scientific Data, 6(1), 180308. https://doi.org/10.1038/sdata.2018.308

Bachman, S. L., Dahl, M. J., Werkle-Bergner, M., Düzel, S., Forlim, C. G., Lindenberger, U., . . Mather, M. (2021). Locus coeruleus MRI contrast is associated with cortical thickness in older adults. Neurobiol Aging, 100, 72-82. https://doi.org/10.1016/j.neurobiolaging.2020.12.019

Beaudet, G., Tsuchida, A., Petit, L., Tzourio, C., Caspers, S., Schreiber, J., . . Mazoyer, B. (2020). Age-Related Changes of Peak Width Skeletonized Mean Diffusivity (PSMD) Across the Adult Lifespan: A Multi-Cohort Study. Front Psychiatry, 11, 342. https://doi.org/10.3389/fpsyt.2020.00342

Bekar, L. K., Wei, H. S., \& Nedergaard, M. (2012). The locus coeruleus-norepinephrine network optimizes coupling of cerebral blood volume with oxygen demand. J Cereb Blood Flow Metab, 32(12), 2135-2145. https://doi.org/10.1038/jcbfm.2012.115

Benveniste, H., Liu, X., Koundal, S., Sanggaard, S., Lee, H., \& Wardlaw, J. (2019). The Glymphatic System and Waste Clearance with Brain Aging: A Review. Gerontology, 65(2), 106-119. https://doi.org/10.1159/000490349

Bertram, L., Böckenhoff, A., Demuth, I., Düzel, S., Eckardt, R., Li, S. C., . . Steinhagen-Thiessen, E. (2014). Cohort profile: The Berlin Aging Study II (BASE-II). Int J Epidemiol, 43(3), 703-712. https://doi.org/10.1093/ije/dyt018

Bhagat, Y. A., \& Beaulieu, C. (2004). Diffusion anisotropy in subcortical white matter and cortical gray matter: Changes with aging and the role of CSF-suppression. Journal of Magnetic Resonance Imaging, 20(2), 216227. https://doi.org/10.1002/imri.20102

Braak, H., \& Del Trecidi, K. (2015). Neuroanatomy and pathology of sporadic Alzheimer's disease. Adv Anat Embryol Cell Biol, 215, 1-162.

Braak, H., Thal, D. R., Ghebremedhin, E., \& Del Tredici, K. (2011). Stages of the pathologic process in Alzheimer disease: age categories from 1 to 100 years. J Neuropathol Exp Neurol, 70(11), 960-969. https://doi.org/10.1097/NEN.0b013e318232a379

Cedernaes, J., Osorio, R. S., Varga, A. W., Kam, K., Schiöth, H. B., \& Benedict, C. (2017). Candidate mechanisms underlying the association between sleep-wake disruptions and Alzheimer's disease. Sleep Medicine Reviews, 31, 102-111. https://doi.org/https://doi.org/10.1016/i.smrv.2016.02.002

Chen, X., Huddleston, D. E., Langley, J., Ahn, S., Barnum, C. J., Factor, S. A., . . Hu, X. (2014). Simultaneous imaging of locus coeruleus and substantia nigra with a quantitative neuromelanin MRI approach. Magn Reson Imaging, 32(10), 1301-1306. https://doi.org/10.1016/i.mri.2014.07.003

Clewett, D. V., Lee, T.-H., Greening, S., Ponzio, A., Margalit, E., \& Mather, M. (2016). Neuromelanin marks the spot: identifying a locus coeruleus biomarker of cognitive reserve in healthy aging. Neurobiology of aging, 37, 117-126. https://doi.org/10.1016/i.neurobiolaging.2015.09.019 
bioRxiv preprint doi: https://doi.org/10.1101/2021.11.23.469621; this version posted November 24,2021 . The copyright holder for this preprint (which was not certified by peer review) is the author/funder, who has granted bioRxiv a license to display the preprint in perpetuity. It is made available under aCC-BY-NC-ND 4.0 International license.

Aging Differences in LC Diffusivity

Dahl, M. J., Mather, M., Düzel, S., Bodammer, N. C., Lindenberger, U., Kühn, S., \& Werkle-Bergner, M. (2019). Rostral locus coeruleus integrity is associated with better memory performance in older adults. Nat Hum Behav, 3(11), 1203-1214. https://doi.org/10.1038/s41562-019-0715-2

Dahl, M. J., Mather, M., Sander, M. C., \& Werkle-Bergner, M. (2020). Noradrenergic Responsiveness Supports Selective Attention across the Adult Lifespan. The Journal of Neuroscience, 40(22), 4372. https://doi.org/10.1523/JNEUROSCI.0398-19.2020

Dahl, M. J., Mather, M., Werkle-Bergner, M., Kennedy, B. L., Guzman, S., Hurth, K., . . Ringman, J. M. (2021). Locus coeruleus integrity is related to tau burden and memory loss in autosomal-dominant Alzheimer's disease. medRxiv, 2020.2011.2016.20232561. https://doi.org/10.1101/2020.11.16.20232561

Dahl, M. J., Mather, M., Werkle-Bergner, M., Kennedy, B. L., Qiao, Y., Shi, Y., \& Ringman, J. M. (2020). Lower MRindexed locus coeruleus integrity in autosomal-dominant Alzheimer's disease is related to cortical tau burden and memory deficits. medRxiv, 2020.2011.2016.20232561. https://doi.org/10.1101/2020.11.16.20232561

Delius, M, J. A., Düzel , S., Gerstorf , D., \& Lindenberger , U. (2015). Berlin Aging Studies (BASE and BASE-II). In Pachana (Ed.), Encyclopedia of geropsychology (pp. 386-395): Springer.

Dinov, I. D., Van Horn, J. D., Lozev, K. M., Magsipoc, R., Petrosyan, P., Liu, Z., . . Toga, A. W. (2009). Efficient, Distributed and Interactive Neuroimaging Data Analysis Using the LONI Pipeline. Frontiers in neuroinformatics, 3, 22-22. https://doi.org/10.3389/neuro.11.022.2009

Edlow, B. L., McNab, J. A., Witzel, T., \& Kinney, H. C. (2016). The Structural Connectome of the Human Central Homeostatic Network. Brain Connect, 6(3), 187-200. https://doi.org/10.1089/brain.2015.0378

Edlow, B. L., Takahashi, E., Wu, O., Benner, T., Dai, G., Bu, L., . . Folkerth, R. D. (2012). Neuroanatomic connectivity of the human ascending arousal system critical to consciousness and its disorders. J Neuropathol Exp Neurol, 71(6), 531-546. https://doi.org/10.1097/NEN.0b013e3182588293

Ehrenberg, A. J., Suemoto, C. K., França Resende, E. d. P., Petersen, C., Leite, R. E. P., Rodriguez, R. D., . . Grinberg, L. T. (2018). Neuropathologic Correlates of Psychiatric Symptoms in Alzheimer's Disease. Journal of Alzheimer's Disease, 66, 115-126. https://doi.org/10.3233/JAD-180688

Elvsåshagen, T., Norbom, L. B., Pedersen, P., Quraishi, S. H., Bjørnerud, A., Malt, U. F., . . Westlye, L. T. (2015). Widespread changes in white matter microstructure after a day of waking and sleep deprivation. PLOS One, 10(5), e0127351. https://doi.org/10.1371/journal.pone.0127351

Giorgi, Galgani, A., Puglisi-Allegra, S., Limanaqi, F., Busceti, C. L., \& Fornai, F. (2020). Locus Coeruleus and neurovascular unit: From its role in physiology to its potential role in Alzheimer's disease pathogenesis. Journal of Neuroscience Research, 98(12), 2406-2434. https://doi.org/https://doi.org/10.1002/jnr.24718

Giorgi, F. S., Galgani, A., Puglisi-Allegra, S., Limanaqi, F., Busceti, C. L., \& Fornai, F. (2020). Locus Coeruleus and neurovascular unit: From its role in physiology to its potential role in Alzheimer's disease pathogenesis. $J$ Neurosci Res, 98(12), 2406-2434. https://doi.org/10.1002/inr.24718

Giustino, T. F., Ramanathan, K. R., Totty, M. S., Miles, O. W., \& Maren, S. (2020). Locus Coeruleus Norepinephrine Drives Stress-Induced Increases in Basolateral Amygdala Firing and Impairs Extinction Learning. J Neurosci, 40(4), 907-916. https://doi.org/10.1523/JNEUROSCl.1092-19.2019

Goldstein, A. N., \& Walker, M. P. (2014). The role of sleep in emotional brain function. Annual review of clinical psychology, 10, 679-708. https://doi.org/10.1146/annurev-clinpsy-032813-153716

Hayat, H., Regev, N., Matosevich, N., Sales, A., Paredes-Rodriguez, E., Krom, A. J., . . Nir, Y. (2020). Locus coeruleus norepinephrine activity mediates sensory-evoked awakenings from sleep. Sci Adv, 6(15), eaaz4232. https://doi.org/10.1126/sciadv.aaz4232

Irwin, M. R., Olmstead, R., \& Carroll, J. E. (2016). Sleep Disturbance, Sleep Duration, and Inflammation: A Systematic Review and Meta-Analysis of Cohort Studies and Experimental Sleep Deprivation. Biol Psychiatry, 80(1), 40-52. https://doi.org/10.1016/i.biopsych.2015.05.014

Iwasa, K., Tasaki, I., \& Gibbons, R. C. (1980). Swelling of nerve fibers associated with action potentials. Science, 210(4467), 338-339. https://doi.org/10.1126/science.7423196

Jacobs, H. I., van Boxtel, M. P., Gronenschild, E. H., Uylings, H. B., Jolles, J., \& Verhey, F. R. (2013). Decreased gray matter diffusivity: a potential early Alzheimer's disease biomarker? Alzheimers Dement, 9(1), 93-97. https://doi.org/10.1016/i.jalz.2011.11.004 
bioRxiv preprint doi: https://doi.org/10.1101/2021.11.23.469621; this version posted November 24,2021 . The copyright holder for this preprint (which was not certified by peer review) is the author/funder, who has granted bioRxiv a license to display the preprint in perpetuity. It is made available under aCC-BY-NC-ND 4.0 International license.

Aging Differences in LC Diffusivity

Kang, S. S., Ahn, E. H., \& Ye, K. (2020). Delta-secretase cleavage of Tau mediates its pathology and propagation in Alzheimer's disease. Exp Mol Med, 52(8), 1275-1287. https://doi.org/10.1038/s12276-020-00494-7

Kantarci, K. (2014). Fractional Anisotropy of the Fornix and Hippocampal Atrophy in Alzheimer's Disease. Frontiers in Aging Neuroscience, 6, 316.

Kantarci, K., Murray, M. E., Schwarz, C. G., Reid, R. I., Przybelski, S. A., Lesnick, T., . . Dickson, D. W. (2017). Whitematter integrity on DTI and the pathologic staging of Alzheimer's disease. Neurobiology of aging, 56, 172179. https://doi.org/10.1016/i.neurobiolaging.2017.04.024

Kassambara, A. rstatix: Pipe-Friendly Framework for Basic Statistical Tests. In (0.7.0 ed.).

Khalsa, S., Hale, J. R., Goldstone, A., Wilson, R. S., Mayhew, S. D., Bagary, M., \& Bagshaw, A. P. (2017). Habitual sleep durations and subjective sleep quality predict white matter differences in the human brain. Neurobiol Sleep Circadian Rhythms, 3, 17-25. https://doi.org/10.1016/i.nbscr.2017.03.001

Khanday, M. A., Somarajan, B. I., Mehta, R., \& Mallick, B. N. (2016). Noradrenaline from Locus Coeruleus Neurons Acts on Pedunculo-Pontine Neurons to Prevent REM Sleep and Induces Its Loss-Associated Effects in Rats. eNeuro, 3(6). https://doi.org/10.1523/ENEURO.0108-16.2016

Kochunov, P., Williamson, D. E., Lancaster, J., Fox, P., Cornell, J., Blangero, J., \& Glahn, D. C. (2012). Fractional anisotropy of water diffusion in cerebral white matter across the lifespan. Neurobiol Aging, 33(1), 9-20. https://doi.org/10.1016/i.neurobiolaging.2010.01.014

Langley, J., Hussain, S., Flores, J. J., Bennett, I. J., \& Hu, X. (2020). Characterization of age-related microstructural changes in locus coeruleus and substantia nigra pars compacta. Neurobiol Aging, 87, 89-97. https://doi.org/10.1016/i.neurobiolaging.2019.11.016

Langley, J., Hussain, S., Huddleston, D. E., Bennett, I. J., \& Hu, X. P. (2021). Impact of Locus Coeruleus and Its Projections on Memory and Aging. Brain Connectivity. https://doi.org/10.1089/brain.2020.0947

Lavoie, C. J., Zeidler, M. R., \& Martin, J. L. (2018). Sleep and aging. Sleep Science and Practice, 2(1), 3. https://doi.org/10.1186/s41606-018-0021-3

Le Bihan, D., Urayama, S., Aso, T., Hanakawa, T., \& Fukuyama, H. (2006). Direct and fast detection of neuronal activation in the human brain with diffusion MRI. Proc Natl Acad Sci U S A, 103(21), 8263-8268. https://doi.org/10.1073/pnas.0600644103

Lee, D. H., Park, J. W., Park, S. H., \& Hong, C. (2015). Have You Ever Seen the Impact of Crossing Fiber in DTI?: Demonstration of the Corticospinal Tract Pathway. PLoS One, 10(7), e0112045. https://doi.org/10.1371/journal.pone.0112045

Lee, T.-H., Greening, S. G., Ueno, T., Clewett, D., Ponzio, A., Sakaki, M., \& Mather, M. (2018). Arousal increases neural gain via the locus coeruleus-noradrenaline system in younger adults but not in older adults. Nature Human Behaviour, 2(5), 356-366. https://doi.org/10.1038/s41562-018-0344-1

Lenth, R. V. (2021). emmeans: Estimated Marginal Means, aka Least-Squares Means. In (1.5.5-1 ed.).

Li, X.-Y., Tang, Z.-C., Sun, Y., Tian, J., Liu, Z.-Y., \& Han, Y. (2016). White matter degeneration in subjective cognitive decline: a diffusion tensor imaging study. Oncotarget, 7(34), 54405-54414. https://doi.org/10.18632/oncotarget.10091

Liu, K. Y., Acosta-Cabronero, J., Cardenas-Blanco, A., Loane, C., Berry, A. J., Betts, M. J., . . Cam-CAN. (2019). In vivo visualization of age-related differences in the locus coeruleus. Neurobiol Aging, 74, 101-111. https://doi.org/10.1016/j.neurobiolaging.2018.10.014

Liu, K. Y., Kievit, R. A., Tsvetanov, K. A., Betts, M. J., Düzel, E., Rowe, J. B., . . Cam-CAN. (2020). Noradrenergicdependent functions are associated with age-related locus coeruleus signal intensity differences. Nat Commun, 11(1), 1712. https://doi.org/10.1038/s41467-020-15410-w

Liu, K. Y., Marijatta, F., Hämmerer, D., Acosta-Cabronero, J., Düzel, E., \& Howard, R. J. (2017). Magnetic resonance imaging of the human locus coeruleus: A systematic review. Neurosci Biobehav Rev, 83, 325-355. https://doi.org/10.1016/i.neubiorev.2017.10.023

Loizou, L. A. (1969). Projections of the nucleus locus coeruleus in the albino rat. Brain Research, 15(2), 563-566. https://doi.org/https://doi.org/10.1016/0006-8993(69)90185-1

Loughlin, S. E., Foote, S. L., \& Fallon, J. H. (1982). Locus coeruleus projections to cortex: Topography, morphology and collateralization. Brain Research Bulletin, 9(1), 287-294.

https://doi.org/https://doi.org/10.1016/0361-9230(82)90142-3 
bioRxiv preprint doi: https://doi.org/10.1101/2021.11.23.469621; this version posted November 24,2021 . The copyright holder for this preprint (which was not certified by peer review) is the author/funder, who has granted bioRxiv a license to display the preprint in perpetuity. It is made available under aCC-BY-NC-ND 4.0 International license.

\section{Aging Differences in LC Diffusivity}

Mander, B. A., Winer, J. R., Jagust, W. J., \& Walker, M. P. (2016). Sleep: A Novel Mechanistic Pathway, Biomarker, and Treatment Target in the Pathology of Alzheimer's Disease? Trends in Neurosciences, 39(8), 552-566. https://doi.org/https://doi.org/10.1016/j.tins.2016.05.002

Mather, M. (2020). The locus coeruleus norepinephrine system role in cognition and how it changes with aging (D. Poeppel, G. Mangung, \& M. Gazzaniga, Eds.). MIT Press.

Mather, M., \& Harley, C. W. (2016). The Locus Coeruleus: Essential for Maintaining Cognitive Function and the Aging Brain. Trends in Cognitive Sciences, 20(3), 214-226. https://doi.org/https://doi.org/10.1016/i.tics.2016.01.001

McGregor, R., \& Siegel, J. M. (2010). Illuminating the locus coeruleus: control of posture and arousal. Nature Neuroscience, 13, 1448.

Medina, \& Gaviria. (2008). Diffusion tensor imaging investigations in Alzheimer's disease: the resurgence of white matter compromise in the cortical dysfunction of the aging brain. Neuropsychiatric disease and treatment, 4(4), 737-742.

Medina, D. A., \& Gaviria, M. (2008). Diffusion tensor imaging investigations in Alzheimer's disease: the resurgence of white matter compromise in the cortical dysfunction of the aging brain. Neuropsychiatr Dis Treat, 4(4), 737-742. https://doi.org/10.2147/ndt.s3381

Morris, L. S., McCall, J. G., Charney, D. S., \& Murrough, J. W. (2020). The role of the locus coeruleus in the generation of pathological anxiety. Brain Neurosci Adv, 4, 2398212820930321. https://doi.org/10.1177/2398212820930321

Morris, L. S., Tan, A., Smith, D. A., Grehl, M., Han-Huang, K., Naidich, T. P., . . Murrough, J. W. (2020). Submillimeter variation in human locus coeruleus is associated with dimensional measures of psychopathology: An in vivo ultra-high field 7-Tesla MRI study. Neuroimage Clin, 25, 102148. https://doi.org/10.1016/j.nicl.2019.102148

Nunes, D., Gil, R., \& Shemesh, N. (2021). A rapid-onset diffusion functional MRI signal reflects neuromorphological coupling dynamics. Neuroimage, 231, 117862. https://doi.org/10.1016/j.neuroimage.2021.117862

O'Donnell, L. J., \& Westin, C. F. (2011). An introduction to diffusion tensor image analysis. Neurosurg Clin N Am, 22(2), 185-196, viii. https://doi.org/10.1016/i.nec.2010.12.004

Oouchi, H., Yamada, K., Sakai, K., Kizu, O., Kubota, T., Ito, H., \& Nishimura, T. (2007). Diffusion Anisotropy Measurement of Brain White Matter Is Affected by Voxel Size: Underestimation Occurs in Areas with Crossing Fibers. American Journal of Neuroradiology, 28(6), 1102. https://doi.org/10.3174/ajnr.A0488

Pal, D., Trivedi, R., Saksena, S., Yadav, A., Kumar, M., Pandey, C. M., . . Gupta, R. K. (2011). Quantification of ageand gender-related changes in diffusion tensor imaging indices in deep grey matter of the normal human brain. J Clin Neurosci, 18(2), 193-196. https://doi.org/10.1016/i.jocn.2010.05.033

Pfefferbaum, A., \& Sullivan, E. V. (2003). Increased brain white matter diffusivity in normal adult aging: relationship to anisotropy and partial voluming. Magn Reson Med, 49(5), 953-961. https://doi.org/10.1002/mrm.10452

Raichle, M. E., Hartman, B. K., Eichling, J. O., \& Sharpe, L. G. (1975). Central noradrenergic regulation of cerebral blood flow and vascular permeability. Proc Natl Acad Sci U S A, 72(9), 3726-3730. https://doi.org/10.1073/pnas.72.9.3726

Rose, S. E., Janke PhD, A. L., \& Chalk, J. B. (2008). Gray and white matter changes in Alzheimer's disease: A diffusion tensor imaging study. Journal of Magnetic Resonance Imaging, 27(1), 20-26. https://doi.org/https://doi.org/10.1002/jmri.21231

Sara, S. J. (2009). The locus coeruleus and noradrenergic modulation of cognition. Nature Reviews Neuroscience, $10,211$.

Sibilia, F., Kehoe, E. G., Farrell, D., Kerskens, C., O'Neill, D., McNulty, J. P., . . Bokde, A. L. W. (2017). Aging-Related Microstructural Alterations Along the Length of the Cingulum Bundle. Brain Connect, 7(6), 366-372. https://doi.org/10.1089/brain.2017.0493

Sjoberg, D. D., Curry, M., Hannum, M., Whiting, K., \& Zabor, E. C. (2021). gtsummary: Presentation-Ready Data Summary and Analytic Result Tables. In (1.3.7 ed.).

Smith, S. M., Jenkinson, M., Woolrich, M. W., Beckmann, C. F., Behrens, T. E., Johansen-Berg, H., . . Matthews, P. M. (2004). Advances in functional and structural MR image analysis and implementation as FSL. Neuroimage, 23 Suppl 1, S208-219. https://doi.org/10.1016/j.neuroimage.2004.07.051 
bioRxiv preprint doi: https://doi.org/10.1101/2021.11.23.469621; this version posted November 24,2021 . The copyright holder for this preprint (which was not certified by peer review) is the author/funder, who has granted bioRxiv a license to display the preprint in perpetuity. It is made available under aCC-BY-NC-ND 4.0 International license.

\section{Aging Differences in LC Diffusivity}

Soares, J. M., Marques, P., Alves, V., \& Sousa, N. (2013). A hitchhiker's guide to diffusion tensor imaging. Frontiers in neuroscience, 7, 31-31. https://doi.org/10.3389/fnins.2013.00031

Sullivan, E. V., \& Pfefferbaum, A. (2006). Diffusion tensor imaging and aging. Neuroscience \& Biobehavioral Reviews, 30(6), 749-761. https://doi.org/https://doi.org/10.1016/j.neubiorev.2006.06.002

Sun, W., Tang, Y., Mather, M., M. Ringman, J., Shi, Y., \& ADNI. (2019). A probabilistic atlas of locus coeruleus pathways to transentorhinalcortex for connectome imaging in Alzheimer's disease. Under review.

Sun, W., Tang, Y., Qiao, Y., Ge, X., Mather, M., Ringman, J. M., . . . Initiative, f. A. s. D. N. (2020). A probabilistic atlas of locus coeruleus pathways to transentorhinal cortex for connectome imaging in Alzheimer's disease. Neuroimage, 223, 117301. https://doi.org/10.1016/i.neuroimage.2020.117301

Svoboda, J., \& Syková, E. (1991). Extracellular space volume changes in the rat spinal cord produced by nerve stimulation and peripheral injury. Brain Res, 560(1-2), 216-224. https://doi.org/10.1016/00068993(91)91235-s

Takahashi, K., Kayama, Y., Lin, J. S., \& Sakai, K. (2010). Locus coeruleus neuronal activity during the sleep-waking cycle in mice. Neuroscience, 169(3), 1115-1126. https://doi.org/10.1016/i.neuroscience.2010.06.009

Talbot, L. S., McGlinchey, E. L., Kaplan, K. A., Dhal, R. E., \& Harvey, A. G. (2010). Sleep deprivation in adolescents and adults: changes in affect. Emotion, 10(6), 831-841. https://doi.org/10.1037/a0020138

Tang, Y., Sun, W., Toga, A. W., Ringman, J. M., \& Shi, Y. (2018). A probabilistic atlas of human brainstem pathways based on connectome imaging data. Neurolmage, 169, 227-239. https://doi.org/https://doi.org/10.1016/j.neuroimage.2017.12.042

Team, R. C. (2020). R: A Language and Environment for Statistical Computing. R Foundation for Statistical Computing. https://www.R-project.org/

Tirosh, N., \& Nevo, U. (2013). Neuronal activity significantly reduces water displacement: DWI of a vital rat spinal cord with no hemodynamic effect. Neuroimage, 76, 98-107.

https://doi.org/10.1016/j.neuroimage.2013.02.065

Tournier, J. D., Smith, R., Raffelt, D., Tabbara, R., Dhollander, T., Pietsch, M., . . Connelly, A. (2019). MRtrix3: A fast, flexible and open software framework for medical image processing and visualisation. Neuroimage, 202, 116137. https://doi.org/10.1016/j.neuroimage.2019.116137

Voineskos, Rajji, T. K., Lobaugh, N. J., Miranda, D., Shenton, M. E., Kennedy, J. L., .. . Mulsant, B. H. (2012). Agerelated decline in white matter tract integrity and cognitive performance: A DTI tractography and structural equation modeling study. Neurobiology of Aging, 33(1), 21-34. https://doi.org/https://doi.org/10.1016/j.neurobiolaging.2010.02.009

Voineskos, A. N., Rajji, T. K., Lobaugh, N. J., Miranda, D., Shenton, M. E., Kennedy, J. L., ... Mulsant, B. H. (2012). Age-related decline in white matter tract integrity and cognitive performance: a DTI tractography and structural equation modeling study. Neurobiol Aging, 33(1), 21-34. https://doi.org/10.1016/j.neurobiolaging.2010.02.009

Voldsbekk, I., Groote, I., Zak, N., Roelfs, D., Geier, O., Due-Tønnessen, P., . . Maximov, I. I. (2021). Sleep and sleep deprivation differentially alter white matter microstructure: A mixed model design utilising advanced diffusion modelling. Neuroimage, 226, 117540. https://doi.org/10.1016/i.neuroimage.2020.117540

Voldsbekk, I., Maximov, I. I., Zak, N., Roelfs, D., Geier, O., Due-Tønnessen, P., . . Groote, I. (2020). Evidence for wakefulness-related changes to extracellular space in human brain white matter from diffusion-weighted MRI. Neuroimage, 212, 116682. https://doi.org/10.1016/j.neuroimage.2020.116682

Weinshenker, D. (2018). Long Road to Ruin: Noradrenergic Dysfunction in Neurodegenerative Disease. Trends Neurosci, 41(4), 211-223. https://doi.org/10.1016/j.tins.2018.01.010

Weston, P. S. J., Simpson, I. J. A., Ryan, N. S., Ourselin, S., \& Fox, N. C. (2015). Diffusion imaging changes in grey matter in Alzheimer's disease: a potential marker of early neurodegeneration. Alzheimer's Research \& Therapy, 7(1), 47. https://doi.org/10.1186/s13195-015-0132-3

Wicham, H. (2017). tidyverse: Easily Install and Load the 'Tidyverse'. R package version 1.2.1. https://CRAN.Rproject.org/package=tidyverse

Wickham, H. (2016). ggplot2: Elegant Graphics for Data Analysis. In: Springer-Verlag New York. 
bioRxiv preprint doi: https://doi.org/10.1101/2021.11.23.469621; this version posted November 24,2021 . The copyright holder for this preprint (which was not certified by peer review) is the author/funder, who has granted bioRxiv a license to display the preprint in perpetuity. It is made available under aCC-BY-NC-ND 4.0 International license.

\section{Aging Differences in LC Diffusivity}

Xie, Y. (2021). knitr: A General-Purpose Package for Dynamic Report Generation in R. In (1.31 ed.).

Yi, S. Y., Barnett, B. R., Torres-Velázquez, M., Zhang, Y., Hurley, S. A., Rowley, P. A., . . Yu, J. J. (2019). Detecting Microglial Density With Quantitative Multi-Compartment Diffusion MRI. Front Neurosci, 13, 81. https://doi.org/10.3389/fnins.2019.00081

Zitting, K. M., Münch, M. Y., Cain, S. W., Wang, W., Wong, A., Ronda, J. M., . . Duffy, J. F. (2018). Young adults are more vulnerable to chronic sleep deficiency and recurrent circadian disruption than older adults. Sci Rep, 8(1), 11052. https://doi.org/10.1038/s41598-018-29358-x 
bioRxiv preprint doi: https://doi.org/10.1101/2021.11.23.469621; this version posted November 24,2021 . The copyright holder for this preprint (which was not certified by peer review) is the author/funder, who has granted bioRxiv a license to display the preprint in perpetuity. It is made available under aCC-BY-NC-ND 4.0 International license.

\section{Aging Differences in LC Diffusivity}

Table 1

Demographics for Each Dataset

Younger Adults $\quad$ Older Adults $\quad p^{\text {a }}$

Berlin Aging Study-II (BASE-II)

Age in Years ${ }^{b}$

$35.90(3.67)$

$75.65(4.05)$

$<0.001$

Sex ${ }^{c}$

0.6

Male

$39(67)$

$154(63)$

Female

19 (33)

89 (37)

Total

58

243

Leipzig Study for Mind-Body-Emotion Interactions (LEMON)

Age in Years

$25.10(3.10)$

$67.60(4.70)$

$<0.001$

Sex

$105(70)$

0.004

Male

$44(30)$

35 (49)

Female

149

$36(51)$

Total

71

Stockholm SLEEPY Brain (SLEEPY)

Age in Years

20-30

65-75

Sex

$6(38)$

0.8

Male

$10(62)$

15 (45)

Female

16

18 (55)

Total

9 (56)

33

Sleep Deprived

16 (48)

0.8

Note. Age in SLEEPY dataset is reported as ranges. 
bioRxiv preprint doi: https://doi.org/10.1101/2021.11.23.469621; this version posted November 24, 2021. The copyright holder for this preprint (which was not certified by peer review) is the author/funder, who has granted bioRxiv a license to display the preprint in perpetuity. It is made available under aCC-BY-NC-ND 4.0 International license.

Aging Differences in LC Diffusivity

${ }^{\text {a }}$ Statistical tests performed: chi-square test of independence (for comparisons across sexes

and sleep deprivation conditions); Wilcoxon rank-sum test (for age). ${ }^{\text {b }}$ Statistics presented:

Mean (SD). ${ }^{\mathrm{c}}$ Statistics presented: $\mathrm{n}$ (\% of total) 
bioRxiv preprint doi: https://doi.org/10.1101/2021.11.23.469621; this version posted November 24,2021 . The copyright holder for this preprint (which was not certified by peer review) is the author/funder, who has granted bioRxiv a license to display the preprint in perpetuity. It is made available under aCC-BY-NC-ND 4.0 International license.

Aging Differences in LC Diffusivity

Table 2

LC-MRI Contrast Sequence Parameters

\begin{tabular}{|c|c|c|}
\hline BASE-II & Item & Duration or Size \\
\hline Scanner & 3-Tesla Siemens Magnetom Tim Trio & \\
\hline Head-coil & 12-channel & \\
\hline Sequence & $\begin{array}{l}\text { High-resolution, two-dimensional T1- } \\
\text { weighted turbo-spin echo (TSE) sequence } \\
\text { aligned perpendicularly to the plane of the } \\
\text { respective participant's brainstem }\end{array}$ & $2 * 5.9$ minutes \\
\hline \multirow[t]{7}{*}{ Parameters } & Repetition Time & $600 \mathrm{~ms}$ \\
\hline & Echo Time & $11 \mathrm{~ms}$ \\
\hline & Inversion Time & \\
\hline & Flip Angle & $120^{\circ}$ \\
\hline & Bandwidth & 287Hz/pixel \\
\hline & FOV & $350 \mathrm{~mm}$ \\
\hline & Slice Thickness & $2.5 \mathrm{~mm}$ isotropic \\
\hline
\end{tabular}


bioRxiv preprint doi: https://doi.org/10.1101/2021.11.23.469621; this version posted November 24,2021 . The copyright holder for this preprint (which was not certified by peer review) is the author/funder, who has granted bioRxiv a license to display the preprint in perpetuity. It is made available under aCC-BY-NC-ND 4.0 International license.

Aging Differences in LC Diffusivity

Table 3

Structural MRI Sequence Parameters in Each Study

Item

Duration or Size

Berlin Aging Study-II (BASE-II)

Scanner

Head coil

Sequence

Parameters

Other
3-Tesla Siemens Magnetom Tim Trio

12-channel

T1-weighted magnetization prepared gradient-echo (MPRAGE)

Repetition Time

Echo Time

Inversion Time

Flip Angle

Bandwidth

FOV

Slice Thickness
9:2 minutes

$2500 \mathrm{~ms}$

$4.77 \mathrm{~ms}$

$1100 \mathrm{~ms}$

$7^{\circ}$

$140 \mathrm{~Hz} /$ pixel

$256 \mathrm{~mm}$

$1 \mathrm{~mm}$ isotropic

The LC-contrast and structural MRI scans were acquired when participants returned for BASE-II evaluations at Time 2. Pre-scan normalize, and 3D distortion correction options were enabled.

\begin{tabular}{|c|c|c|}
\hline \multicolumn{3}{|c|}{ Leipzig Study for Mind-Body-Emotion Interactions (LEMON) } \\
\hline Scanner & 3-Tesla Siemens Magnetom Verio & \\
\hline Head coil & 32-channel & \\
\hline Sequence & $\begin{array}{c}\text { Magnetization Prepared } 2 \text { Rapid } \\
\text { Acquisition Gradient Echoes (MP2RAGE) }\end{array}$ & $8: 22$ minutes \\
\hline \multirow[t]{5}{*}{ Parameters } & Repetition Time & $5000 \mathrm{~ms}$ \\
\hline & Echo Time & $2.92 \mathrm{~ms}$ \\
\hline & Inversion Time $1 / 2$ & $700 / 2500 \mathrm{~ms}$ \\
\hline & Flip Angle $1 / 2$ & $4 / 5^{\circ}$ \\
\hline & Bandwidth & $240 \mathrm{~Hz} /$ pixel \\
\hline
\end{tabular}


bioRxiv preprint doi: https://doi.org/10.1101/2021.11.23.469621; this version posted November 24,2021 . The copyright holder for this preprint (which was not certified by peer review) is the author/funder, who has granted bioRxiv a license to display the preprint in perpetuity. It is made available under aCC-BY-NC-ND 4.0 International license.

Aging Differences in LC Diffusivity

FOV $256 \mathrm{~mm}$

Slice Thickness

$1 \mathrm{~mm}$ isotropic

Other

For more information please see Babayan et al., (2019)

\section{Stockholm SLEEPY Brain}

Scanner

3-Tesla General Electric Discovery

Head coil

8-channel

Sequence

Sagittal orientation with BRAVO

$8: 22$ minutes

Parameters

Repetition Time

$6400 \mathrm{~ms}$

Echo Time

$2.81 \mathrm{~ms}$

Inversion Time

$450 \mathrm{~ms}$

Flip Angle

$11^{\circ}$

Bandwidth

$122 \mathrm{~Hz} /$ pixel

FOV

$240 \mathrm{~mm}$

Slice Thickness

$1 \mathrm{~mm}$ isotropic

Other

For more information please see Nilsonne et al., (2016) 
bioRxiv preprint doi: $h$ ttps://doi.org/10.1101/2021.11.23.469621; this version posted November 24,2021 . The copyright holder for this preprint (which was not certified by peer review) is the author/funder, who has granted bioRxiv a license to display the preprint in perpetuity. It is made available under aCC-BY-NC-ND 4.0 International license.

Aging Differences in LC Diffusivity

Table 4

Diffusion MRI Sequence Parameters in Each Study

Item

Duration or Size

Berlin Aging Study-II (BASE-II)

Scanner

Head coil

Sequence

Parameters
3-Tesla Siemens Magnetom Tim Trio

12-channel

Transverse plane and seven volumes collected without diffusion weighting $(b=0)$.

Repetition Time

$11000 \mathrm{~ms}$

Echo Time

98ms

Gradient Directions

60

Diffusion Weighting

$\mathrm{b}=1,000 \mathrm{~s} / \mathrm{mm}^{2}$

Bandwidth

$1628 \mathrm{~Hz} /$ pixel

FOV

$218 \mathrm{~mm}$

Slice Thickness
$1.7 \mathrm{~mm}$ isotropic

Generalized auto-calibrating partially parallel acquisitions (GRAPPA) acceleration factor $=2$ in single-shot, echo-planar imaging. For more details, see Dahl et al., (2019a) and Bender et al., (2019).

\begin{tabular}{|c|c|c|}
\hline \multicolumn{3}{|c|}{ Leipzig Study for Mind-Body-Emotion Interactions (LEMON) } \\
\hline Scanner & 3-Tesla Siemens Magnetom Verio & \\
\hline Head coil & 32-channel & \\
\hline Sequence & $\begin{array}{c}\text { Transverse plane and seven volumes collected } \\
\text { without diffusion weighting }(b=0) .\end{array}$ & $9: 27$ minutes \\
\hline \multirow[t]{5}{*}{ Parameters } & Repetition Time & $7000 \mathrm{~ms}$ \\
\hline & Echo Time & $80 \mathrm{~ms}$ \\
\hline & Gradient Directions & 60 \\
\hline & Diffusion Weighting & $\mathrm{b}=1,000 \mathrm{~s} / \mathrm{mm}^{2}$ \\
\hline & Bandwidth & $1502 \mathrm{~Hz} /$ pixel \\
\hline
\end{tabular}


bioRxiv preprint doi: https://doi.org/10.1101/2021.11.23.469621; this version posted November 24,2021 . The copyright holder for this preprint (which was not certified by peer review) is the author/funder, who has granted bioRxiv a license to display the preprint in perpetuity. It is made available under aCC-BY-NC-ND 4.0 International license.

Aging Differences in LC Diffusivity

FOV

$220 \mathrm{~mm}$

Slice Thickness

$1.7 \mathrm{~mm}$ isotropic

Other

For more information please see (Babayan et al., 2019)

\section{Stockholm SLEEPY Brain}

Scanner

3-Tesla General Electric Discovery

Head coil

8-channel

Sequence

Sagittal plane and five volumes collected without diffusion weighting $(b=0)$.

Parameters

Repetition Time

Echo Time

Gradient Directions

Diffusion Weighting

Bandwidth

FOV

Slice Thickness
5:55 minutes

$7000 \mathrm{~ms}$

$80 \mathrm{~ms}$

45

$\mathrm{b}=1,000 \mathrm{~s} / \mathrm{mm}^{2}$

$1502 \mathrm{~Hz} /$ pixel

$220 \mathrm{~mm}$

$2.3 \mathrm{~mm}$ isotropic

Other

Diffusion-weighted imaging was only collected during the second scanning session of this study, yielding a total of 26 sleep deprived and 27 non sleep deprived subjects, randomly assigned. For more information please see (Nilsonne et al., 2016) 
bioRxiv preprint doi: https://doi.org/10.1101/2021.11.23.469621; this version posted November 24,2021 . The copyright holder for this preprint (which was not certified by peer review) is the author/funder, who has granted bioRxiv a license to display the preprint in perpetuity. It is made available under aCC-BY-NC-ND 4.0 International license.

Aging Differences in LC Diffusivity

\section{Table 5}

Younger adults LC-MRI contrast correlations with confidence intervals

\begin{tabular}{lc}
\hline Variable & LC-MRI Contrast \\
\hline Noradrenergic bundle FA - Left hemisphere & -.07 \\
& {$[-.31, .18]$} \\
Noradrenergic bundle FA - Right hemisphere & -.09 \\
& {$[-.33, .16]$} \\
Locus Coeruleus FA - Left hemisphere & -.02 \\
& {$[-.27, .23]$} \\
Locus Coeruleus FA - Right hemisphere & -.06 \\
& {$[-.30, .19]$} \\
Frontopontine FA - Left hemisphere & .04 \\
& {$[-.21, .29]$} \\
Frontopontine FA - Right hemisphere & .15 \\
& {$[-.10, .39]$}
\end{tabular}

Note. Values in square brackets indicate the $95 \%$ confidence interval for each correlation.

The confidence interval is a plausible range of population correlations that could have caused the sample correlation (Cumming, 2014). 
bioRxiv preprint doi: https://doi.org/10.1101/2021.11.23.469621; this version posted November 24,2021 . The copyright holder for this preprint (which was not certified by peer review) is the author/funder, who has granted bioRxiv a license to display the preprint in perpetuity. It is made available under aCC-BY-NC-ND 4.0 International license.

Aging Differences in LC Diffusivity

\section{Table 6}

Older adults LC-MRI contrast correlations with confidence intervals

\begin{tabular}{lc}
\hline Variable & LC-MRI Cont \\
\hline Noradrenergic bundle FA - Left hemisphere & -.03 \\
& {$[-.15, .10]$} \\
Noradrenergic bundle FA - Right hemisphere & -.08 \\
& {$[-.20, .05]$} \\
Locus Coeruleus FA - Left hemisphere & .05 \\
& {$[-.08, .17]$} \\
Locus Coeruleus FA - Right hemisphere & -.10 \\
& {$[-.23, .02]$} \\
Frontopontine FA - Left hemisphere & -.06 \\
& {$[-.19, .06]$} \\
Frontopontine FA - Right hemisphere & -.02 \\
& {$[-.14, .11]$}
\end{tabular}

Note. Values in square brackets indicate the $95 \%$ confidence interval for each correlation.

The confidence interval is a plausible range of population correlations that could have caused the sample correlation (Cumming, 2014). 
bioRxiv preprint doi: https://doi.org/10.1101/2021.11.23.469621; this version posted November 24, 2021. The copyright holder for this preprint (which was not certified by peer review) is the author/funder, who has granted bioRxiv a license to display the preprint in perpetuity. It is made available under aCC-BY-NC-ND 4.0 International license.

Aging Differences in LC Diffusivity

Table 7

BASE-II Fractional Anisotropy Mixed ANOVA

\begin{tabular}{|c|c|c|c|c|c|c|}
\hline Variable & $F$ & $d f_{1}^{G G}$ & $d f_{2}^{G G}$ & $M S E$ & $p$ & $\widehat{\eta}_{G}^{2}$ \\
\hline Age (Younger, Older) & 1.05 & 1 & 299 & 0.01 & .306 & .001 \\
\hline Gender (Female, Male) & 7.33 & 1 & 299 & 0.01 & .007 & .007 \\
\hline ROI (LC, Noradrenergic Bundle, Frontopontine) & 598.17 & 1.57 & 468.27 & 0.01 & $<.001$ & .426 \\
\hline Hemisphere (Left, Right) & 125.52 & 1 & 299 & 0.00 & $<.001$ & .049 \\
\hline Age $\times$ Gender & 1.21 & 1 & 299 & 0.01 & .273 & .001 \\
\hline Age $\times$ ROI & 27.18 & 1.57 & 468.27 & 0.01 & $<.001$ & .033 \\
\hline Gender $\times$ ROI & 1.97 & 1.57 & 468.27 & 0.01 & .151 & .002 \\
\hline Age $\times$ Hemisphere & 0.00 & 1 & 299 & 0.00 & .980 & .000 \\
\hline Gender $\times$ Hemisphere & 0.17 & 1 & 299 & 0.00 & .682 & .000 \\
\hline ROI $\times$ Hemisphere & 73.81 & 1.62 & 483.01 & 0.00 & $<.001$ & .051 \\
\hline Age $\times$ Gender $\times$ ROI & 0.46 & 1.57 & 468.27 & 0.01 & .584 & .001 \\
\hline Age $\times$ Gender $\times$ Hemisphere & 0.46 & 1 & 299 & 0.00 & .497 & .000 \\
\hline Age $\times$ ROI $\times$ Hemisphere & 6.49 & 1.62 & 483.01 & 0.00 & .003 & .005 \\
\hline Gender $\times$ ROI $\times$ Hemisphere & 0.25 & 1.62 & 483.01 & 0.00 & .729 & .000 \\
\hline Age $\times$ Gender $\times$ ROI $\times$ Hemisphere & 0.17 & 1.62 & 483.01 & 0.00 & .802 & .000 \\
\hline
\end{tabular}


bioRxiv preprint doi: https://doi.org/10.1101/2021.11.23.469621; this version posted November 24, 2021. The copyright holder for this preprint (which was not certified by peer review) is the author/funder, who has granted bioRxiv a license to display the preprint in perpetuity. It is made available under aCC-BY-NC-ND 4.0 International license.

Aging Differences in LC Diffusivity

Table 8

LEMON Fractional Anisotropy Mixed ANOVA

\begin{tabular}{|c|c|c|c|c|c|c|}
\hline Variable & $F$ & $d f_{1}^{G G}$ & $d f_{2}^{G G}$ & $M S E$ & $p$ & $\widehat{\eta}_{G}^{2}$ \\
\hline Age (Younger, Older) & 0.26 & 1 & 216 & 0.01 & .608 & .001 \\
\hline Gender (Female, Male) & 0.72 & 1 & 216 & 0.01 & .396 & .002 \\
\hline ROI (LC, Noradrenergic Bundle, Frontopontine) & 761.97 & 1.79 & 386.34 & 0.00 & $<.001$ & .513 \\
\hline Hemisphere (Left, Right) & 412.73 & 1 & 216 & 0.00 & $<.001$ & .130 \\
\hline Age $\times$ Gender & 0.38 & 1 & 216 & 0.01 & .539 & .001 \\
\hline Age $\times$ ROI & 26.07 & 1.79 & 386.34 & 0.00 & $<.001$ & .035 \\
\hline Gender $\times$ ROI & 2.22 & 1.79 & 386.34 & 0.00 & .116 & .003 \\
\hline Age $\times$ Hemisphere & 9.17 & 1 & 216 & 0.00 & .003 & .003 \\
\hline Gender $\times$ Hemisphere & 1.69 & 1 & 216 & 0.00 & .195 & .001 \\
\hline ROI $\times$ Hemisphere & 308.54 & 1.63 & 352.15 & 0.00 & $<.001$ & .194 \\
\hline Age $\times$ Gender $\times$ ROI & 0.57 & 1.79 & 386.34 & 0.00 & .546 & .001 \\
\hline Age $\times$ Gender $\times$ Hemisphere & 4.70 & 1 & 216 & 0.00 & .031 & .002 \\
\hline Age $\times$ ROI $\times$ Hemisphere & 5.50 & 1.63 & 352.15 & 0.00 & .008 & .004 \\
\hline Gender $\times$ ROI $\times$ Hemisphere & 1.56 & 1.63 & 352.15 & 0.00 & .214 & .001 \\
\hline Age $\times$ Gender $\times$ ROI $\times$ Hemisphere & 2.58 & 1.63 & 352.15 & 0.00 & .088 & .002 \\
\hline
\end{tabular}


bioRxiv preprint doi: https://doi.org/10.1101/2021.11.23.469621; this version posted November 24, 2021. The copyright holder for this preprint (which was not certified by peer review) is the author/funder, who has granted bioRxiv a license to display the preprint in perpetuity. It is made available under aCC-BY-NC-ND 4.0 International license.

Aging Differences in LC Diffusivity

Table 9

SLEEPY Fractional Anisotropy Mixed ANOVA

\begin{tabular}{|c|c|c|c|c|c|c|}
\hline Variable & $F$ & $d f_{1}^{G G}$ & $d f_{2}^{G G}$ & $M S E$ & $p$ & $\widehat{\eta}_{G}^{2}$ \\
\hline Age (Younger, Older) & 1.32 & 1 & 41 & 0.01 & .257 & .011 \\
\hline Sleep Condition (Rested, Deprived) & 1.19 & 1 & 41 & 0.01 & .282 & .010 \\
\hline ROI (LC, Noradrenergic Bundle, Frontopontine) & 115.99 & 1.76 & 72.17 & 0.00 & $<.001$ & .540 \\
\hline Hemisphere (Left, Right) & 15.92 & 1 & 41 & 0.00 & $<.001$ & .040 \\
\hline Age $\times$ Sleep Condition & 2.44 & 1 & 41 & 0.01 & .126 & .020 \\
\hline Age $\times$ ROI & 3.09 & 1.76 & 72.17 & 0.00 & .058 & .030 \\
\hline Sleep Condition $\times$ ROI & 2.48 & 1.76 & 72.17 & 0.00 & .098 & .024 \\
\hline Age $\times$ Hemisphere & 1.27 & 1 & 41 & 0.00 & .267 & .003 \\
\hline Sleep Condition $\times$ Hemisphere & 1.22 & 1 & 41 & 0.00 & .275 & .003 \\
\hline ROI $\times$ Hemisphere & 18.37 & 1.57 & 64.45 & 0.00 & $<.001$ & .054 \\
\hline Age $\times$ Sleep Condition $\times$ ROI & 3.12 & 1.76 & 72.17 & 0.00 & .056 & .031 \\
\hline Age $\times$ Sleep Condition $\times$ Hemisphere & 2.08 & 1 & 41 & 0.00 & .157 & .005 \\
\hline Age $\times$ ROI $\times$ Hemisphere & 0.34 & 1.57 & 64.45 & 0.00 & .659 & .001 \\
\hline Sleep Condition $\times$ ROI $\times$ Hemisphere & 0.24 & 1.57 & 64.45 & 0.00 & .732 & .001 \\
\hline Age $\times$ Sleep Condition $\times$ ROI $\times$ Hemisphere & 0.24 & 1.57 & 64.45 & 0.00 & .731 & .001 \\
\hline
\end{tabular}


bioRxiv preprint doi: https://doi.org/10.1101/2021.11.23.469621; this version posted November 24,2021 . The copyright holder for this preprint (which was not certified by peer review) is the author/funder, who has granted bioRxiv a license to display the preprint in perpetuity. It is made available under aCC-BY-NC-ND 4.0 International license.

Aging Differences in LC Diffusivity

Table 10

BASE-II Fractional Anisotropy Means, Standard Error, Degrees of Freedom and 95\% Confidence Intervals

\begin{tabular}{lcccccc}
\hline BASE-II & \multicolumn{2}{c}{ Locus Coeruleus } & \multicolumn{2}{c}{ Noradrenergic Bundle } & \multicolumn{2}{c}{ Frontopontine Tract } \\
\cline { 2 - 6 } & Young Adult & Older Adult & Young Adult & Older Adult & Young Adult & Older Adult \\
\hline Left Hemisphere & & & & & \\
$M^{\mathrm{a}}$ & 0.396 & 0.426 & 0.421 & 0.403 & 0.563 & 0.567 \\
SE & 0.01 & 0.005 & 0.004 & 0.002 & 0.008 & 0.004 \\
Lower Cl & 0.377 & 0.417 & 0.413 & 0.4 & 0.547 & 0.559 \\
Upper Cl & 0.416 & 0.436 & 0.428 & 0.407 & 0.58 & 0.574 \\
\hline Right Hemisphere & & & & & 0.515 & 0.522 \\
$M^{\text {a }}$ & 0.397 & 0.452 & 0.356 & 0.309 & 0.515 & 0.004 \\
SE & 0.014 & 0.007 & 0.004 & 0.002 & 0.008 & 0.515 \\
Lower Cl & 0.369 & 0.439 & 0.348 & 0.306 & 0.5 & 0.529 \\
Upper Cl & 0.424 & 0.465 & 0.363 & 0.313 & 0.53 & \\
\hline
\end{tabular}

Note. $\mathrm{Cl}=$ confidence interval

a degrees of freedom $=299$. 
bioRxiv preprint doi: https://doi.org/10.1101/2021.11.23.469621; this version posted November 24,2021 . The copyright holder for this preprint (which was not certified by peer review) is the author/funder, who has granted bioRxiv a license to display the preprint in perpetuity. It is made available under aCC-BY-NC-ND 4.0 International license.

Aging Differences in LC Diffusivity

Table 11

LEMON Fractional Anisotropy Means, Standard Error, Degrees of Freedom and 95\% Confidence Intervals

\begin{tabular}{lcccccc}
\hline LEMON & \multicolumn{2}{c}{ Locus Coeruleus } & \multicolumn{2}{c}{ Noradrenergic Bundle } & \multicolumn{2}{c}{ Frontopontine Tract } \\
\cline { 2 - 6 } & Young Adult & Older Adult & Young Adult & Older Adult & Young Adult & Older Adult \\
\hline Left Hemisphere & & & & & 0.582 \\
$M^{\mathrm{a}}$ & 0.427 & 0.459 & 0.445 & 0.427 & 0.584 & 0.008 \\
SE & 0.005 & 0.006 & 0.003 & 0.005 & 0.006 & 0.567 \\
Lower Cl & 0.418 & 0.446 & 0.438 & 0.418 & 0.572 & 0.597 \\
Upper Cl & 0.437 & 0.472 & 0.451 & 0.436 & 0.595 & 0.503 \\
\hline Right Hemisphere & & & & & 0.497 & 0.007 \\
$M^{\text {a }}$ & 0.473 & 0.487 & 0.365 & 0.315 & 0.497 \\
SE & 0.007 & 0.009 & 0.003 & 0.004 & 0.005 & 0.489 \\
Lower Cl & 0.46 & 0.47 & 0.359 & 0.308 & 0.487 & 0.517 \\
Upper Cl & 0.486 & 0.505 & 0.37 & 0.323 & 0.508 & \\
\hline
\end{tabular}

Note. $\mathrm{Cl}=$ confidence interval

a degrees of freedom $=216$. 
bioRxiv preprint doi: https://doi.org/10.1101/2021.11.23.469621; this version posted November $24,2021$. The copyright holder for this preprint (which was not certified by peer review) is the author/funder, who has granted bioRxiv a license to display the preprint in perpetuity. It is made available under aCC-BY-NC-ND 4.0 International license.

Aging Differences in LC Diffusivity

Table 12

SLEEPY Fractional Anisotropy Means, Standard Error, Degrees of Freedom and 95\% Confidence Intervals

\begin{tabular}{|c|c|c|c|c|c|c|}
\hline \multirow[t]{2}{*}{ SLEEPY } & \multicolumn{2}{|c|}{ Locus Coeruleus } & \multicolumn{2}{|c|}{ Noradrenergic Bundle } & \multicolumn{2}{|c|}{ Frontopontine Tract } \\
\hline & Young Adult & Older Adult & Young Adult & Older Adult & Young Adult & Older Adult \\
\hline \multicolumn{7}{|c|}{ Left Hemisphere, Rested } \\
\hline$M^{\mathrm{a}}$ & 0.405 & 0.399 & 0.323 & 0.315 & 0.475 & 0.446 \\
\hline SE & 0.027 & 0.019 & 0.01 & 0.007 & 0.029 & 0.02 \\
\hline Lower Cl & 0.35 & 0.36 & 0.303 & 0.301 & 0.417 & 0.405 \\
\hline Upper Cl & 0.46 & 0.437 & 0.344 & 0.33 & 0.533 & 0.486 \\
\hline \multicolumn{7}{|c|}{ Left Hemisphere, Deprived } \\
\hline$M^{\mathrm{a}}$ & 0.343 & 0.395 & 0.35 & 0.311 & 0.469 & 0.463 \\
\hline$S E$ & 0.025 & 0.018 & 0.009 & 0.007 & 0.027 & 0.019 \\
\hline Lower $\mathrm{Cl}$ & 0.292 & 0.358 & 0.331 & 0.298 & 0.415 & 0.424 \\
\hline Upper Cl & 0.394 & 0.432 & 0.369 & 0.325 & 0.523 & 0.503 \\
\hline \multicolumn{7}{|c|}{ Right Hemisphere, Rested } \\
\hline$M^{a}$ & 0.435 & 0.394 & 0.272 & 0.249 & 0.49 & 0.415 \\
\hline$S E$ & 0.023 & 0.016 & 0.007 & 0.005 & 0.028 & 0.02 \\
\hline Lower $\mathrm{Cl}$ & 0.389 & 0.361 & 0.257 & 0.239 & 0.433 & 0.375 \\
\hline Upper Cl & 0.482 & 0.427 & 0.287 & 0.26 & 0.547 & 0.455 \\
\hline \multicolumn{7}{|c|}{ Right Hemisphere, Deprived } \\
\hline$M^{\mathrm{a}}$ & 0.339 & 0.404 & 0.282 & 0.246 & 0.44 & 0.43 \\
\hline$S E$ & 0.021 & 0.016 & 0.007 & 0.005 & 0.026 & 0.019 \\
\hline Lower Cl & 0.295 & 0.372 & 0.268 & 0.236 & 0.387 & 0.392 \\
\hline Upper Cl & 0.382 & 0.436 & 0.296 & 0.256 & 0.493 & 0.469 \\
\hline
\end{tabular}

Note. $\mathrm{Cl}=$ confidence interval.

${ }^{\text {a }}$ degrees of freedom $=41$. 
bioRxiv preprint doi: https://doi.org/10.1101/2021.11.23.469621; this version posted November 24, 2021. The copyright holder for this preprint (which was not certified by peer review) is the author/funder, who has granted bioRxiv a license to display the preprint in perpetuity. It is made available under aCC-BY-NC-ND 4.0 International license.

\section{Aging Differences in LC Diffusivity}

\section{Figure 1}

The ROI atlases of the Locus Coeruleus, Noradrenergic Bundle, and Frontopontine Tract

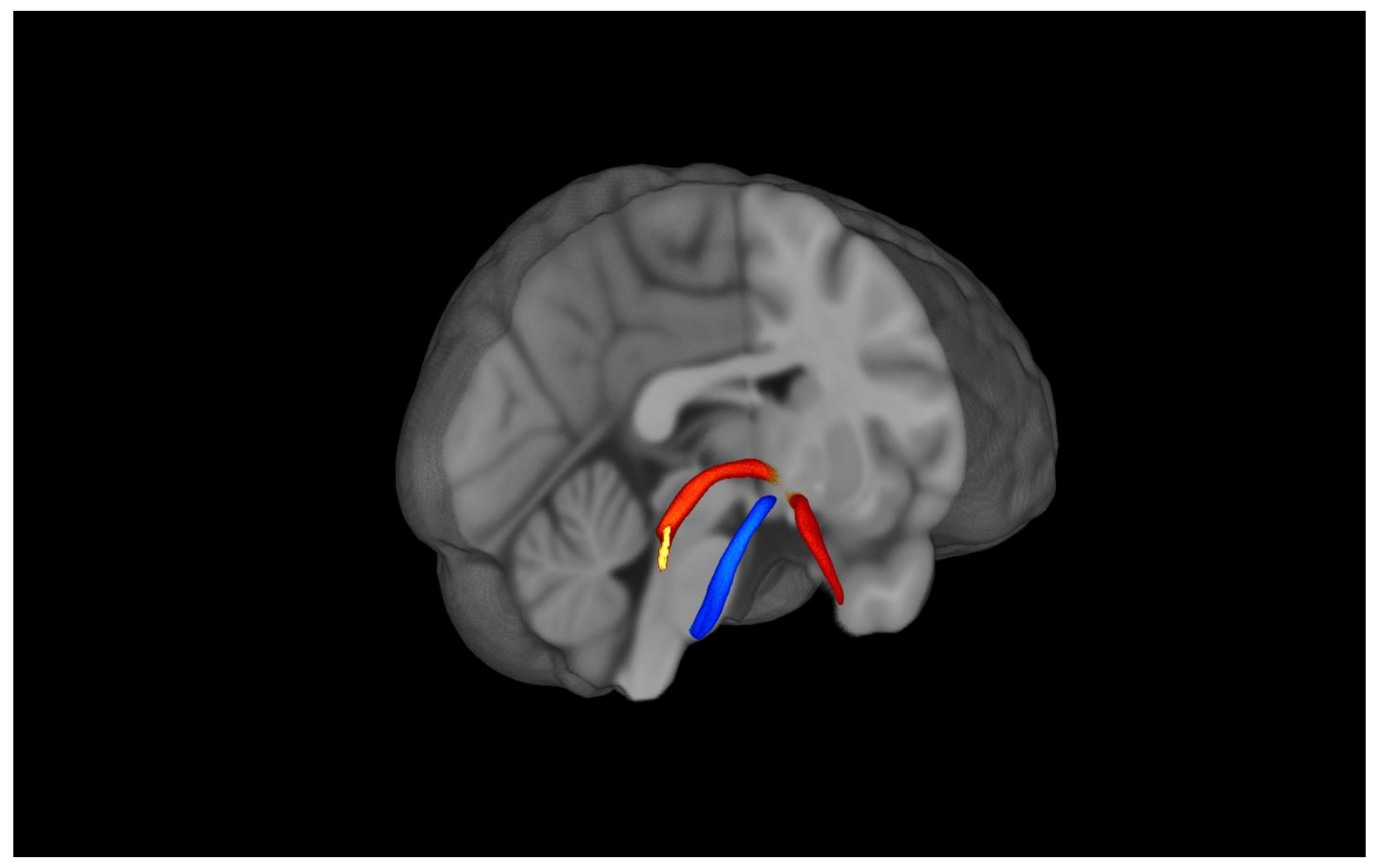

Note. Figure 1 displays the locus coeruleus (yellow), noradrenergic bundle (red), and frontopontine

(blue) tracts registered to MNI152 space. The noradrenergic bundle is one continuous bundle (part of the temporal lobe segment is not pictured). 
bioRxiv preprint doi: https://doi.org/10.1101/2021.11.23.469621. this version posted November 24, 2021. The copyright holder for this preprint (which was not certified by peer review) is the author/funder, who has granted bioRxiv a license to display the preprint in perpetuity. It is made available under aCC-BY-NC-ND 4.0 International license.

Aging Differences in LC Diffusivity

\section{Figure 2}

BASE-II Fractional Anisotropy in Left and Right Locus Coeruleus and Noradrenergic Bundles in Younger and Older Adults

A

$$
\begin{aligned}
& \text { Left Locus } \\
& \text { Coeruleus }
\end{aligned}
$$

0.8

$t_{\text {Welch }}(75.98)=-2.35$

$p=0.021$

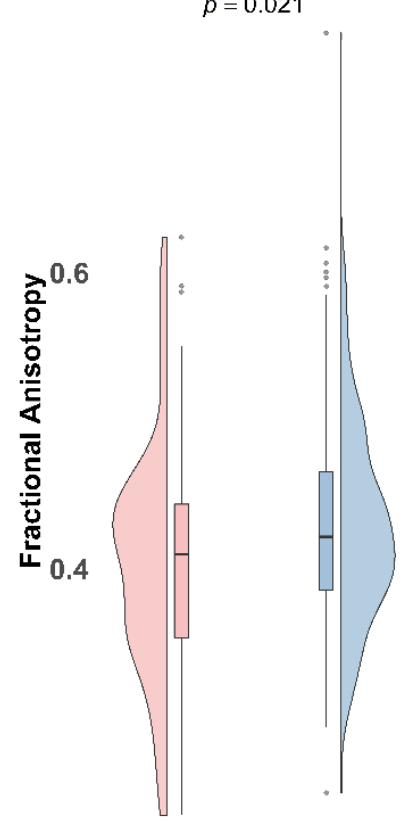

0.2
B Right Locus

$t_{\text {Welch }}(83.84)=-3.41$

$p=0.001$

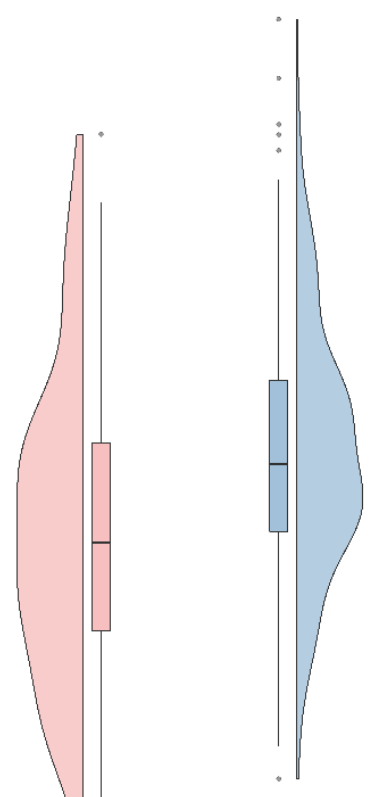

C Left Noradrenergic Bundle

$t_{\text {welch }}(107.42)=5.12$

$p<0.001$
D Right Noradrenergic Bundle

$t_{\text {Welch }}(107.89)=14.64$ $\rho<0.001$
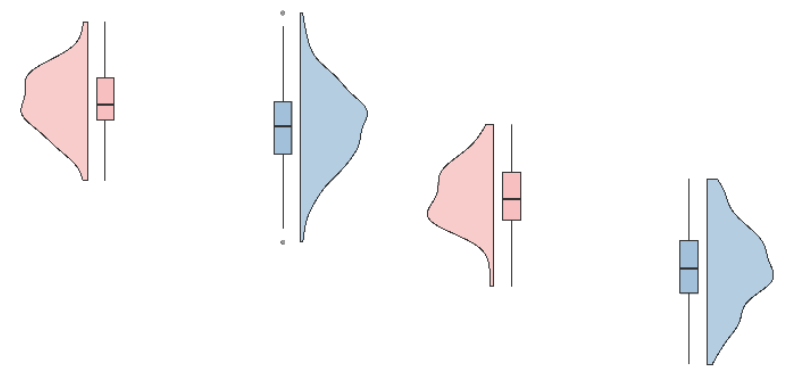

Younger < Older

Younger $<$ Older

Younger > Older

Age 固 Younger 固 Older

Younger > Older

Note. Figure 2 displays fractional anisotropy between younger and older adults from the BASE-II cohort.

In the left locus coeruleus (A) and right locus coeruleus (B), we observed lower fractional anisotropy in younger adults, compared to older adults. In the left noradrenergic bundle $(C)$ and right noradrenergic bundle (D) we observed higher fractional anisotropy in younger adults, relative to older adults. 
bioRxiv preprint doi: https://doi.org/10.1101/2021.11.23.469621; this version posted November 24,2021 . The copyright holder for this preprint (which was not certified by peer review) is the author/funder, who has granted bioRxiv a license to display the preprint in perpetuity. It is made available under aCC-BY-NC-ND 4.0 International license.

Aging Differences in LC Diffusivity

\section{Figure 3}

LEMON Fractional Anisotropy in Left and Right Locus Coeruleus and Noradrenergic Bundles in Younger and Older Adults

A

$$
\begin{aligned}
& \text { Left Locus } \\
& \text { Coeruleus }
\end{aligned}
$$

0.8
B

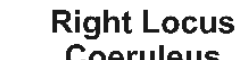

$t_{\text {welch }}(176.74)=-1.92$ $\rho=0.056$

\section{Left Noradrenergic Bundle}

$t_{\text {Welch }}(200.22)=3.32$

$p=0.001$

\section{Right Noradrenergic} Bundle

$t_{\text {Welch }}(115.68)=14.44$ $p<0.001$

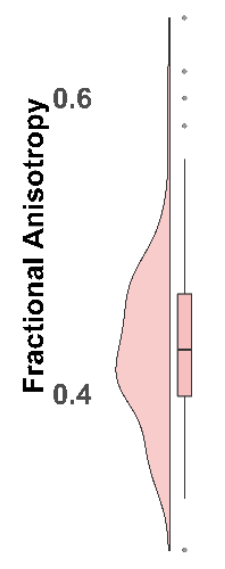

0.2

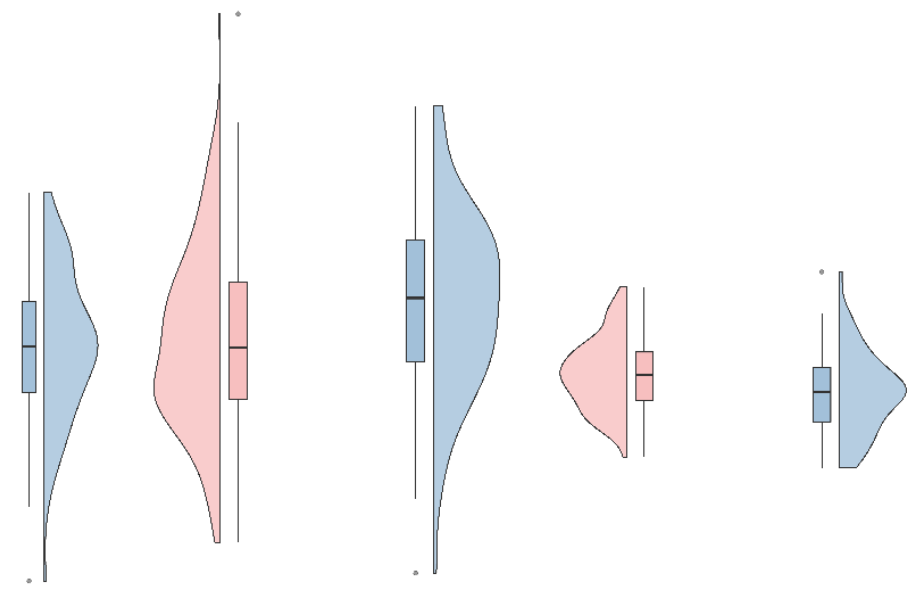

Younger < Older

AgeGi

Younger $>$ Older

国 Older

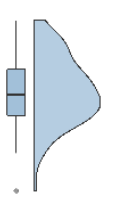

$\sum \mapsto$

Younger > Older

Note. Figure 3 displays our BASE-II replicated fractional anisotropy findings between younger and older adults in the LEMON dataset. In the left locus coeruleus (A) and right locus coeruleus (B), we observed lower fractional anisotropy in younger adults, compared to older adults. In the left noradrenergic bundle (C) and right noradrenergic bundle (D) we observed higher fractional anisotropy in younger adults, relative to older adults. 
bioRxiv preprint doi: https://doi.org/10.1101/2021.11.23.469621; this version posted November 24,2021 . The copyright holder for this preprint (which was not certified by peer review) is the author/funder, who has granted bioRxiv a license to display the preprint in perpetuity. It is made available under aCC-BY-NC-ND 4.0 International license.

Aging Differences in LC Diffusivity

\section{Figure 4}

SLEEPY Brain Fractional Anisotropy in Left and Right Locus Coeruleus and Noradrenergic Bundles in Younger and Older Adults

A

0.8

$t_{\text {Student }}(13.19)=0.82$

$p=0.42$

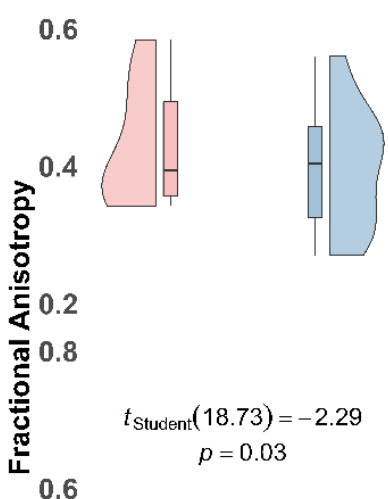

0.4

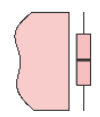

0.2
B

$\begin{gathered}\text { Right } \\ \text { Locus } \\ \text { Coeruleus }\end{gathered}$
$t_{\text {Student }}(10.37)=1.15$
$p=0.27$

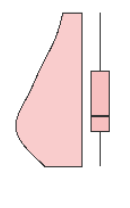

$t_{\text {Student }}(19.67)=-2.1$ $p=0.04$
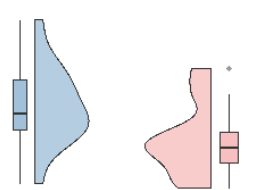

Younger
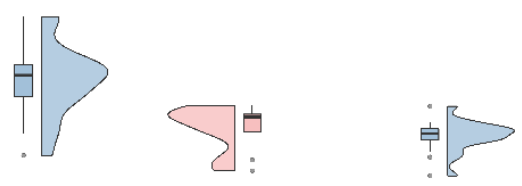

$t_{\text {Student }}(13.51)=3.06$

$p=0.01$

Older

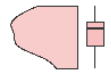

Older

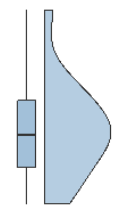

Age 圆 Younger 圆 Older
Left

radrenergic Bundle

$t_{\text {Student }}(11.6)=0.93$

$p=0.37$

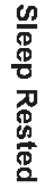

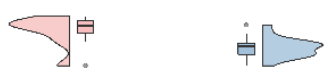

$t_{\text {Student }}(14.57)=4.55$

$p<0.001$

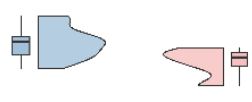

Younger

Older

Note. Figure 4 displays fractional anisotropy between younger and older adults in either the sleep rested or sleep deprived conditions. In the left (A) and right (B) locus coeruleus, we observed no significant differences in fractional anisotropy between young and older adults in the sleep rested condition. However, in the sleep deprived condition, younger adults displayed significantly lower fractional anisotropy, compared to older adults. In the left noradrenergic bundle (C) we observed no significant differences between young and older adult fractional anisotropy in the sleep rested condition. In the sleep deprived condition ( $C$ - row 2 ), younger adults had significantly higher fractional anisotropy, 
bioRxiv preprint doi: https://doi.org/10.1101/2021.11.23.469621; this version posted November 24,2021 . The copyright holder for this preprint (which was not certified by peer review) is the author/funder, who has granted bioRxiv a license to display the preprint in perpetuity. It is made available under aCC-BY-NC-ND 4.0 International license.

\section{Aging Differences in LC Diffusivity}

relative to older adults. In the right noradrenergic bundle (D) younger adults, compared to older adults, had significantly higher fractional anisotropy in the sleep rested condition. Fractional anisotropy differences were more pronounced in the sleep deprived condition. 
bioRxiv preprint doi: https://doi.org/10.1101/2021.11.23,469621: this version posted November 24,2021 . The copyright holder for this preprint (which was not certified by peer review) is the author/funder, who has granted bioRxiv a license to display the preprint in perpetuity. It is made available under aCC-BY-NC-ND 4.0 International license.

Aging Differences in LC Diffusivity

\section{Figure 5}

SLEEPY Brain Fractional Anisotropy in Left and Right Locus Coeruleus and Noradrenergic Bundles between Younger and Older Adults

A

$0.8 \quad t_{\text {Student }}(10.57)=2.18$
$p=0.05$
Left
Locus
Coeruleus

0.6

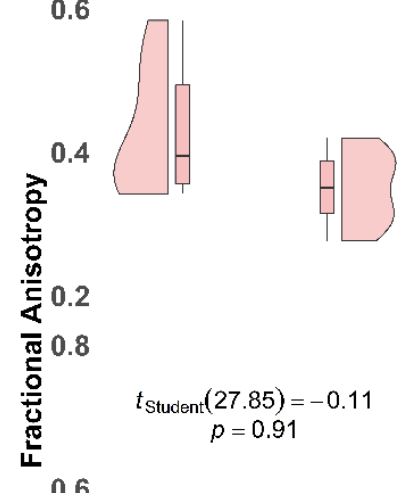

0.6

0.4

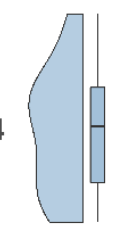

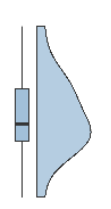

No Yes
B

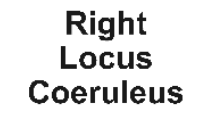

$t_{\text {Student }}(13.23)=2.5$
C
Noradrenergic Bundle

$t_{\text {Student }}(15.65)=-1.31$ $p=0.21$

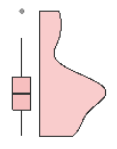

$$
\begin{gathered}
t_{\text {Student }}(29.63)=-0.31 \\
p=0.75
\end{gathered}
$$
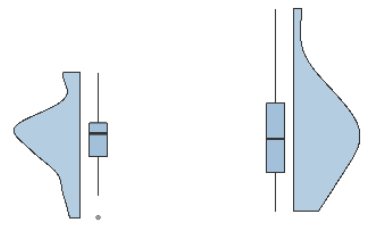

No

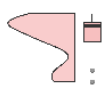

$t_{\text {Student }}(32.68)=0.42$ $p=0.67$

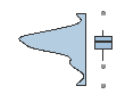

Yes
Sleep Deprived?

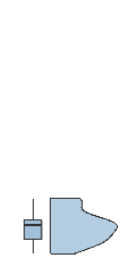

Yes

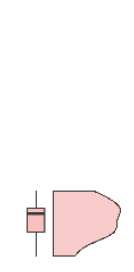

$t_{\text {Student }}(30.15)=0.51$
$p=0.61$

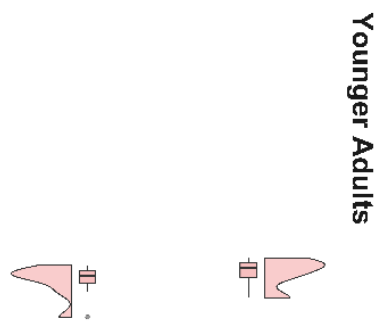
D Right Noradrenergic Bundle

$t_{\text {Student }}\left(\begin{array}{c}15.95)=-0.93 \\ p=0.36\end{array}\right.$

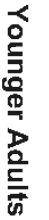

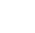

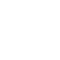

0.2

Note. Figure 5 displays fractional anisotropy between sleep rested or sleep deprived young and older adults. In the left locus coeruleus (A) and right locus coeruleus (B) we observed significantly higher fractional anisotropy in sleep rested young adults, compared to sleep deprived young adults. We observed no significant difference of fractional anisotropy between sleep rested and sleep deprived older adults in the left or right locus coeruleus. In the left noradrenergic bundle (C) and right noradrenergic bundle (D) we observed no significant difference in fractional anisotropy in sleep rested or sleep deprived younger adults; nor sleep rested or sleep deprived older adults. 
bioRxiv preprint doi: https://doi.org/10.1101/2021.11.23.469621; this version posted November 24,2021 . The copyright holder for this preprint (which was not certified by peer review) is the author/funder, who has granted bioRxiv a license to display the preprint in perpetuity. It is made available under aCC-BY-NC-ND 4.0 International license.

Aging Differences in LC Diffusivity

Figure 6

BASE-II Fractional Anisotropy Along the Noradrenergic Bundle

A

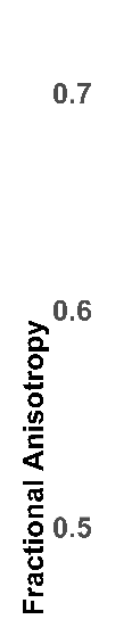

0.4

0.30
Left Noradrenergic Bundle

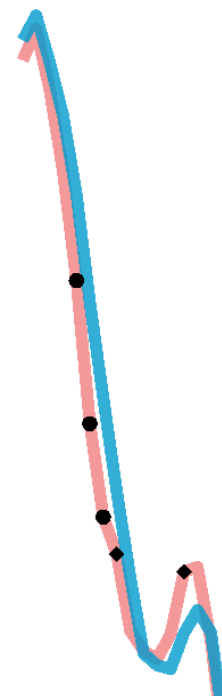

10
1

20
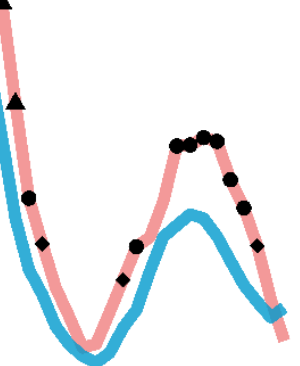

B Right Noradrenergic Bundle

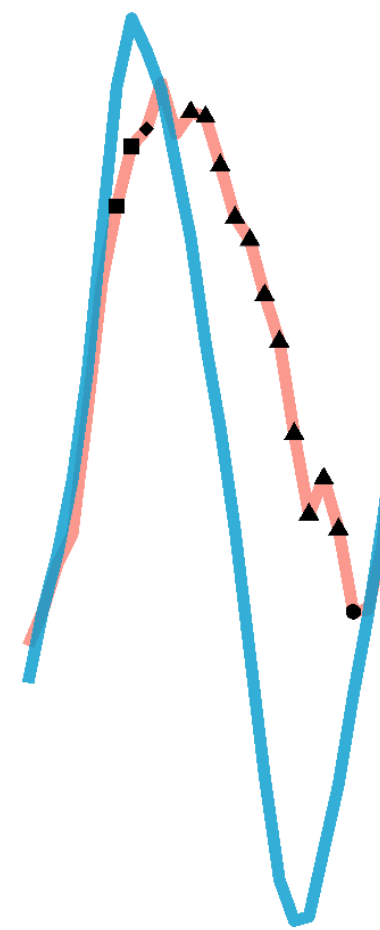

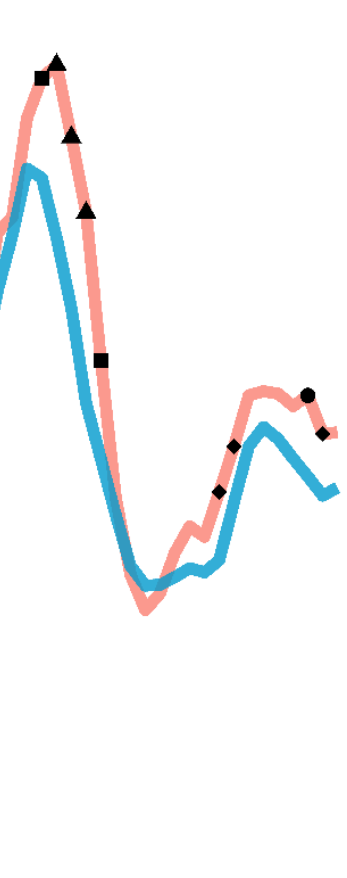

20

30

40

50 Points Along Tract Significance level $\bullet^{*} \bullet \bullet^{* *} \|^{* * *} \Delta * * *$ ns Age $\equiv$ Younger $\equiv$ Older

Note. ns = not significant; ns not assigned shape. Fractional anisotropy differences between younger and older adults are shown along the noradrenergic bundle. The bundle was divided into 50 equidistant points and mean fractional anisotropy was calculated for each age group at each point. Younger adults had significantly lower fractional anisotropy in the first 10 points of the noradrenergic bundles which would correspond to the area of the locus coeruleus. In contrast, around the entorhinal cortex, younger adults show higher fractional anisotropy, compared to older adults.

$* \mathrm{p} \leq .05 .{ }^{* *} \mathrm{p} \leq .01 .{ }^{* * *} \mathrm{p} \leq .001 .{ }^{* * * *} \mathrm{p} \leq .0001$. FDR adjusted. 
Aging Differences in LC Diffusivity

\section{Figure 7}

LEMON Fractional Anisotropy Along the Noradrenergic Bundle

A

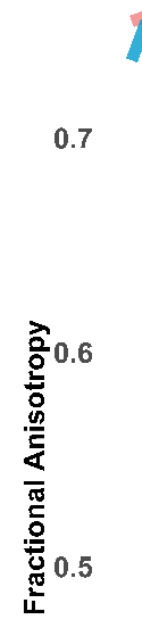

0.4
Left Noradrenergic Bundle

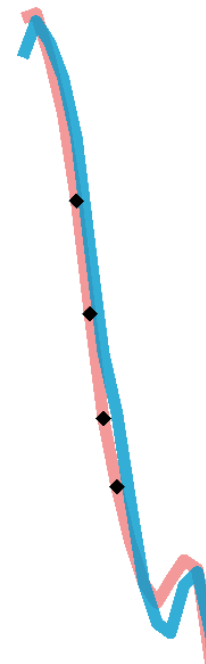

0

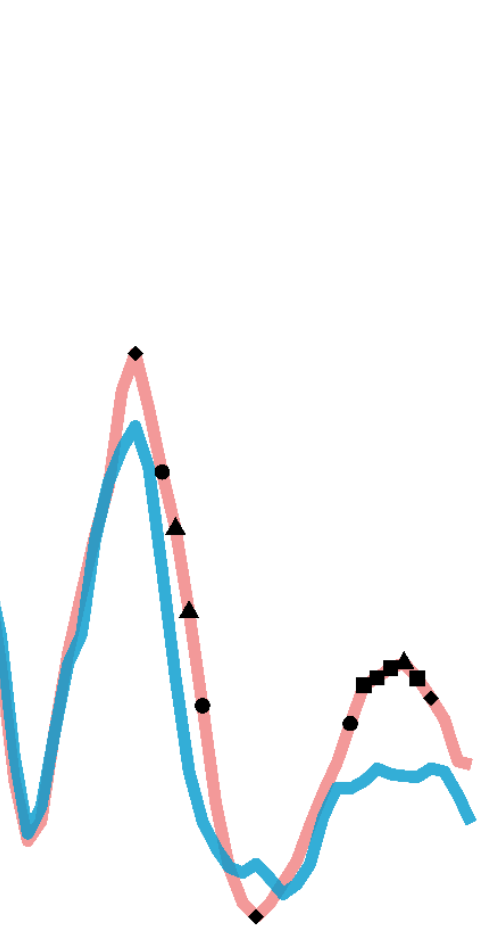

20
30
40
B Right Noradrenergic Bundle

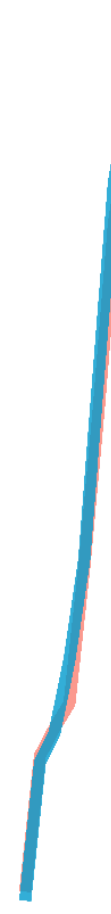

10

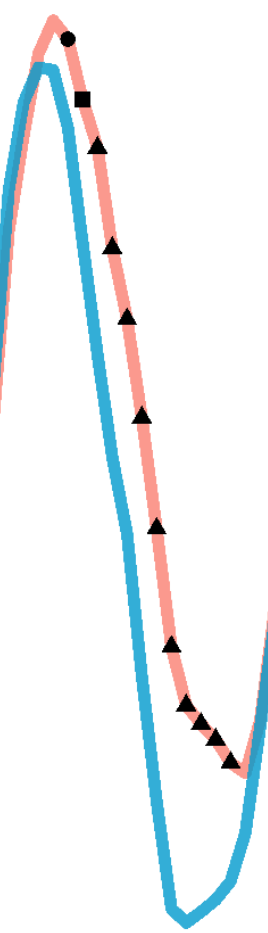

20

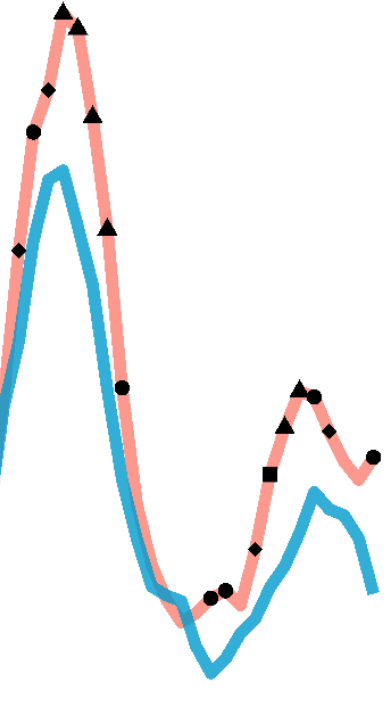

30

40

50

ns Age $=$ Younger $=$ Older

Note. $\mathrm{ns}=$ not significant; ns not assigned shape. Fractional anisotropy differences between LEMON

younger and older adults are shown along the noradrenergic bundle. The bundle was divided into 50 equidistant points and mean fractional anisotropy was calculated for each age group at each point.

Younger adults had significantly lower fractional anisotropy in the first 10 points of the noradrenergic bundle, more so in the left than right, which would correspond to the area of the locus coeruleus. In contrast, younger adults showed higher fractional anisotropy and significantly greater differences around the entorhinal cortex, compared to older adults.

$* p \leq .05 .^{* *} p \leq .01 . * * * p \leq .001 . * * * * p \leq .0001$. FDR adjusted. 
bioRxiv preprint doi: https://doi.org/10.1101/2021.11.23.469621; this version posted November 24,2021 . The copyright holder for this preprint (which was not certified by peer review) is the author/funder, who has granted bioRxiv a license to display the preprint in perpetuity. It is made available under aCC-BY-NC-ND 4.0 International license.

Aging Differences in LC Diffusivity

Figure 8

SLEEPY Fractional Anisotropy Along the Noradrenergic Bundle between Sleep Rested and Sleep Deprived Younger or Older Adults

A Left Noradrenergic Bundle Rested

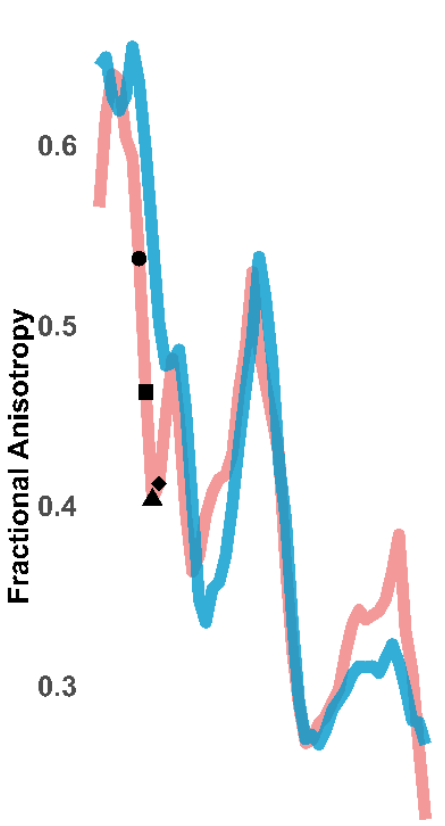

0.2

\section{B Right Noradrenergic Bundle Rested \\ Deprived}

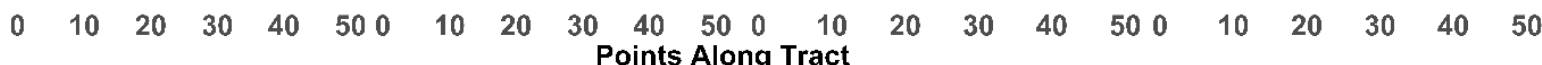
Significance level $\bullet^{*} \bullet * * * * \star \Delta * * *$ ns Age $\square$ Younger $\equiv$ Older
}

Note. ns = not significant; ns not assigned shape. Fractional anisotropy differences between SLEEPY younger and older adults, either sleep rested or sleep deprived, are shown along the noradrenergic bundle. The bundle was divided into 50 equidistant points and mean fractional anisotropy was calculated for each age group at each point. Younger adults display significantly lower fractional anisotropy in the first 10 points (reflecting the locus coeruleus) of the left noradrenergic bundle, when sleep rested.

$* \mathrm{p} \leq .05 .{ }^{* *} \mathrm{p} \leq .01 .{ }^{* * *} \mathrm{p} \leq .001 .{ }^{* * * *} \mathrm{p} \leq .0001$. FDR adjusted. 